OPEN ACCESS

Edited by:

Luis Cardona,

University of Barcelona, Spain

Reviewed by:

Andrea Raya Rey,

Consejo Nacional de Investigaciones

Científicas y Técnicas (CONICET),

Argentina

Andrea Walters,

University of Tasmania, Australia

*Correspondence:

Jonathan Handley

jonathan.m.handley@gmail.com

Maria P. Dias

maria.dias@birdlife.org

Specialty section:

This article was submitted to

Marine Conservation

and Sustainability,

a section of the journal

Frontiers in Marine Science

Received: 04 September 2020 Accepted: 11 December 2020

Published: 20 January 2021

Citation:

Handley J, Rouyer M-M,

Pearmain EJ, Warwick-Evans $V$,

Teschke K, Hinke JT, Lynch H, Emmerson L, Southwell C, Griffith G, Cárdenas CA, Franco AMA, Trathan $P$ and Dias MP (2021) Marine Important

Bird and Biodiversity Areas for Penguins in Antarctica, Targets

for Conservation Action.

Front. Mar. Sci. 7:602972.

doi: 10.3389/fmars.2020.602972

\section{Marine Important Bird and Biodiversity Areas for Penguins in Antarctica, Targets for Conservation Action}

\author{
Jonathan Handley ${ }^{*}$, Marie-Morgane Rouyer ${ }^{2}$, Elizabeth J. Pearmain ${ }^{1}$, \\ Victoria Warwick-Evans ${ }^{3}$, Katharina Teschke ${ }^{4,5}$, Jefferson T. Hinke ${ }^{6}$, Heather Lynch ${ }^{7,8}$, \\ Louise Emmerson ${ }^{9}$, Colin Southwell 9 , Gary Griffith ${ }^{10}$, César A. Cárdenas ${ }^{11}$, \\ Aldina M. A. Franco ${ }^{2}$, Phil Trathan ${ }^{3}$ and Maria P. Dias ${ }^{1,12 *}$
}

\begin{abstract}
${ }^{1}$ BirdLife International, Cambridge, United Kingdom, ${ }^{2}$ School of Environmental Sciences, University of East Anglia, Norwich, United Kingdom, ${ }^{3}$ British Antarctic Survey, Cambridge, United Kingdom, ${ }^{4}$ Alfred Wegener Institute, Helmholtz Centre for Polar and Marine Research, Bremerhaven, Germany, ${ }^{5}$ Helmholtz Institute for Functional Marine Biodiversity at the University Oldenburg (HIFMB), Oldenburg, Germany, ${ }^{6}$ Antarctic Ecosystem Research Division, Southwest Fisheries Science Center, National Marine Fisheries Service, National Oceanic and Atmospheric Administration, La Jolla, CA, United States, ${ }^{7}$ Department of Ecology and Evolution, Stony Brook University, Stony Brook, NY, United States, ${ }^{8}$ Institute for Advanced Computational Science, Stony Brook University, Stony Brook, NY, United States, ${ }^{9}$ Australian Antarctic Division, Department of Agriculture, Water and the Environment, Kingston, TAS, Australia, ${ }^{10}$ Norsk Polarinstitutt/Norwegian Polar Institute, Tromsø, Norway, " ${ }^{11}$ Departamento Científico, Instituto Antártico Chileno, Punta Arenas, Chile, ${ }^{12}$ MARE Marine and Environmental Sciences Centre, ISPA - Instituto Universitário, Lisbon, Portugal
\end{abstract}

Global targets for area-based conservation and management must move beyond threshold-based targets alone and must account for the quality of such areas. In the Southern Ocean around Antarctica, a region where key biodiversity faces unprecedented risks from climate change and where there is a growing demand to extract resources, a number of marine areas have been afforded enhanced conservation or management measures through two adopted marine protected areas (MPAs). However, evidence suggests that additional high quality areas could benefit from a proposed network of MPAs. Penguins offer a particular opportunity to identify high quality areas because these birds, as highly visible central-place foragers, are considered indicator species whose populations reflect the state of the surrounding marine environment. We compiled a comprehensive dataset of the location of penguin colonies and their associated abundance estimates in Antarctica. We then estimated the at-sea distribution of birds based on information derived from tracking data and through the application of a modified foraging radius approach with a density decay function to identify some of the most important marine areas for chick-rearing adult penguins throughout waters surrounding Antarctica following the Important Bird and Biodiversity Area (IBA) framework. Additionally, we assessed how marine IBAs overlapped with the currently adopted and proposed network of key management areas (primarily MPAs), and how the krill fishery likely overlapped with marine IBAs over the past five decades. We identified 63 marine IBAs throughout Antarctic waters and found that were the proposed MPAs to be adopted, the permanent conservation of high quality areas for 
penguin species would increase by between 49 and 100\% depending on the species. Furthermore, our data show that, despite a generally contracting range of operation by the krill fishery in Antarctica over the past five decades, a consistently disproportionate amount of krill is being harvested within marine IBAs compared to the total area in which the fishery operates. Our results support the designation of the proposed MPA network and offer additional guidance as to where decision-makers should act before further perturbation occurs in the Antarctic marine ecosystem.

Keywords: marine protected area, fisheries, Spheniscidae, Pygoscelis, Aptenodytes, CCAMLR, marine IBA

\section{INTRODUCTION}

The last decade has seen various efforts to address the past and current impacts of anthropogenic pressures on the marine environment, and the likely direct and indirect effects climate change will have on marine ecosystems in the future (Halpern et al., 2015; IPCC, 2019; Brooks et al., 2020). Key global drivers of these efforts have been the agreements between nations to achieve the Strategic Plan for Biodiversity (CBD, 2010) and the Sustainable Development Goals (SDGs) (UN General Assembly, 2015). These international agreements, coupled with other longstanding multinational efforts such as the Food and Agriculture Organisation's (FAO) voluntary Code of Conduct for Responsible Fisheries (CCRF, 2018), look to achieve the sustainable use of marine resources along with the preservation of non-target species populations relying on a given ecosystem (FAO CCRF, Aichi Target 6 and SDG 14). One such mechanism to achieve this has been the call to conserve $10 \%$ of coastal ( $0-12$ nautical miles) and marine areas through effective management of protected areas (encompassed in Aichi Target 11); noting that protected area objectives may range from strictly protected through to sustainable use (Dudley, 2008). More recently, several other [higher] percentage-based targets have been suggested for achieving the 2,050 Vision for Biodiversity (Bhola et al., 2020). However, percentage-based targets alone have several shortcomings that may reduce the effectiveness of sites, especially when poorly managed or inappropriately designed to abate pressures (Watson et al., 2014; Visconti et al., 2019). Therefore, new targets recommend to account for the quality of all sites of global significance for biodiversity, and that these be documented, retained, and restored through protected areas or other effective area-based conservation measures (IPBES, 2019; Visconti et al., 2019; Zhao et al., 2020).

In the Southern Ocean and seas that surround Antarctica, the marine environment is governed through the Commission for the Conservation of Antarctic Marine Living Resources (CCAMLR). Particular concerns for CCAMLR include the risks to biodiversity given climate change (IPCC, 2019) and a growing demand for marine living resources (Rintoul et al., 2018; Chown and Brooks, 2019; Hindell et al., 2020). A key aim of CCAMLR is to minimize the risks associated with these pressures through the conservation and rational use of marine resources within the Southern Ocean (CCAMLR, 2018b). Significant progress has already been made toward achieving this aim through numerous mechanisms that include the designation of Marine
Protected Areas (MPAs) (CCAMLR, 2009, 2016; Brooks, 2013; Sylvester and Brooks, 2020). To date, two MPAs have been adopted in waters surrounding mainland Antarctica and the nearby islands (CCAMLR, 2009, 2016). Furthermore, three more MPAs (CCAMLR, 2019a,b,c), and a potential fourth still in the planning phase (Griffith et al., 2019), have been proposed following international collaborative efforts, including the review and assessment of numerous data sources (Sylvester and Brooks, 2020; Teschke et al., 2020). However, consensus (a requirement by CCAMLR for the implementation of management measures) on the designation of the proposed MPAs has not been met (CCAMLR, 2019c).

Seabirds and the status of their populations can provide critical insights on the state of their surrounding marine environment, hence, they are often considered as indicator, or sentinel taxa (Furness and Camphuysen, 1997; Boersma, 2008; Gagne et al., 2018; Velarde et al., 2019). Certain species might be considered as "elucidating" sentinels, whereby species provide an observable link between physical processes in the marine environment and biological responses (Hazen et al., 2019). Alternatively, certain species may be considered as "leading" sentinels, whereby population level responses in these species precede observable change in responses of other species or the ecosystem (Hazen et al., 2019). The penguin species that breed in Antarctica and forage in the Southern Ocean, feed extensively on krill or are ice-obligates, and are exemplar species for studying the potential links between system fluctuations and predator populations (e.g., fisheries pressures: Hinke et al., 2017; Trathan et al., 2018; Watters et al., 2020), or Antarctic marine ecosystem responses to environmental perturbations (e.g., climate change: Jenouvrier et al., 2014; Johnson et al., 2019; Emmerson et al., 2015; Trathan et al., 2019). Indeed, evidence already shows that penguin populations in particular are at risk from overexploitation of resources and climate change (Boersma et al., 2019; Dias et al., 2019; Ropert-Coudert et al., 2019). The potential risk of fishing for Antarctic krill, a fishery with an interest for expansion, likely has the greatest potential to directly affect penguin species at some sites through competition for resources; especially the pygoscelid penguin species that breed throughout Antarctica but mainly on the Antarctic Peninsula (Trathan et al., 2014; Nicol and Foster, 2016; Chown and Brooks, 2019; Watters et al., 2020).

Given the foraging ecology of penguins during their breeding period, with foraging ranges that are spatially restricted by the need to regularly (e.g., daily) provision developing 
offspring, penguins are well-suited for protection via areabased management tools (ABMT). Such tools include the establishment and effective management of MPAs (Oppel et al., 2018; Boersma et al., 2019; Ropert-Coudert et al., 2019). In particular, MPAs, or other ABMTs, can be most effective when they specifically take into consideration the distribution of a species most important areas at-sea. Identification of marine Important Bird and Biodiversity Areas (marine IBAs) provides a mechanism to determine where these most important atsea areas are in a global context, as these are areas assessed against a standardized and internationally agreed upon set of criteria for all bird species (Supplementary Appendix: Marine IBAs) (Lascelles et al., 2016; Donald et al., 2018; Waliczky et al., 2018). The identification of areas as IBAs provides a targeted opportunity through which governments, multilateral environmental agreements and businesses, can determine the efforts required to conserve a network of sites that are essential for maintaining the populations and habitats of birds and their associated biodiversity (Waliczky et al., 2018). The protection of these areas can also support sustained provision of ecosystem services. Furthermore, recent evidence has shown that in MPAs where fisheries operate and where the spatiotemporal distribution of marine IBAs are effectively accounted for in their design and management plans, these MPAs can provide effective conservation opportunities for seabird species and other marine top predators through appropriately designed spatiotemporal closures of fisheries operations (Heerah et al., 2019; Johnson et al., 2019; Handley et al., 2020).

Identifying marine IBAs in waters surrounding Antarctica has only been considered based on the at sea distribution of birds from colonies on the Antarctic Peninsula and nearby islands (Dias et al., 2018a,b). No attempt has been made to identify marine IBAs based on the likely at sea distribution of birds from colonies located elsewhere on mainland Antarctica; waters under the jurisdiction of CCAMLR. Given marine spatial planning (MSP) has been deemed a critical tool toward the conservation of penguin species (Boersma et al., 2019; Ropert-Coudert et al., 2019) and that marine IBAs can support MSP initiatives (Heerah et al., 2019; Johnson et al., 2019; Handley et al., 2020), the main objective of this study is to identify a network of marine IBAs for penguins breeding in Antarctica. We considered four species, the Adélie (Pygoscelis adeliae), Chinstrap (Pygoscelis antarcticus), Gentoo (Pygoscelis papua) and Emperor Penguins (Aptenodytes forsteri), which either have large proportions of their global populations breeding in Antarctica, or are endemic to Antarctica (Supplementary Appendix: Penguin species considered). We then investigated the percentage overlap of marine IBAs with the adopted and proposed key management areas (primarily the MPA network) to determine what advantage these management areas could offer penguin species in terms of conserving some of their most important global areas at sea. We also aim to recognize key risks and threats which may be associated with marine IBAs, with a primary focus on the potential pressures from the krill fishery (Hinke et al., 2017; Trathan et al., 2018; Watters et al., 2020). Therefore, we investigated whether or not a disproportionate amount of krill biomass was caught within or beyond the bounds of marine IBAs, within our study area. We focused our analysis on chick-rearing adult birds, a critical phase of the annual cycle for these birds in terms of the requirement to provision developing offspring and this being a period when birds tend to aggregate most at sea (Ratcliffe and Trathan, 2011; Oppel et al., 2018). As marine IBAs are a subset of Key Biodiversity Areas (IUCN, 2016), sites which contribute to the global persistence of biodiversity, results from this study support spatial planning analyses already undertaken, and offer new insights into spatial planning needs within the CAMLR Convention Area $\left(\right.$ see: $\left.{ }^{1}\right)$.

\section{MATERIALS AND METHODS}

\section{Species Overview}

We focus on identifying marine IBAs for chick-rearing adult birds during the breeding season (Figure 1), because this is the time when birds typically have the most constrained foraging range as they must return regularly to breeding colonies to feed dependent offspring (Ropert-Coudert et al., 2004; Lescroël and Bost, 2005). Exact timing of breeding does fluctuate from year to year (Black, 2016) and for the Adélie penguins can be related to breeding site latitude (Ainley, 2002; Emmerson et al., 2011), however, the critical months for summer breeders typically include November to February, while for the Emperor Penguins critical months include August to mid-December. If the duration of provisioning trips exceeds a critical threshold or birds are unable to capture sufficient prey within a given time period, reduced breeding success (number of chicks surviving to crèche per nest) can occur (Takahashi et al., 2003; Croll et al., 2006; Emmerson et al., 2015; Black, 2016). Krill forms an important part of the diet for all four penguin species (Ratcliffe and Trathan, 2011). Typically, Gentoo and Emperor Penguins have a mixed diet, which includes krill as well as fish and squid (Ratcliffe and Trathan, 2011). Whereas, Adélie and Chinstrap Penguins are dietary specialists (Table 1) especially at the Antarctica Peninsula - and are thus particularly susceptible to changes in krill availability and the impact of this on breeding success (Miller et al., 2009; Herman et al., 2017; Youngflesh et al., 2017).

\section{Study Region and Key Management Areas}

Our region of interest for identifying marine IBAs was within CCAMLR MPA planning domains 1, 3, 4, 7, 8 and 9, those contiguous to mainland Antarctica and the nearby islands (Figure 2). The key management areas we considered (see also Supplementary Appendix: Study area and key spatial data) were the MPA planning domains, their respective adopted or proposed MPAs (CCAMLR, 2009, 2016, 2019a,b,c), an MPA planning area (Griffith et al., 2019) and the Voluntary Restricted Zones (VRZs, ${ }^{2}$ ) along the Antarctic Peninsula (Figure 2). The VRZs are a region in which $85 \%$ of krill fishing companies agreed a voluntary permanent stop to krill fishing between certain dates depending on the region (Antarctic Peninsula: 1 October - 1 February, Gerlache Strait: 15 October - 15 February, South Shetland Islands: 1 November - 1 March).

\footnotetext{
${ }^{1}$ https://www.ccamlr.org/en/organisation/convention-area

${ }^{2}$ https://www.ark-krill.org/ark-voluntary-measures
} 


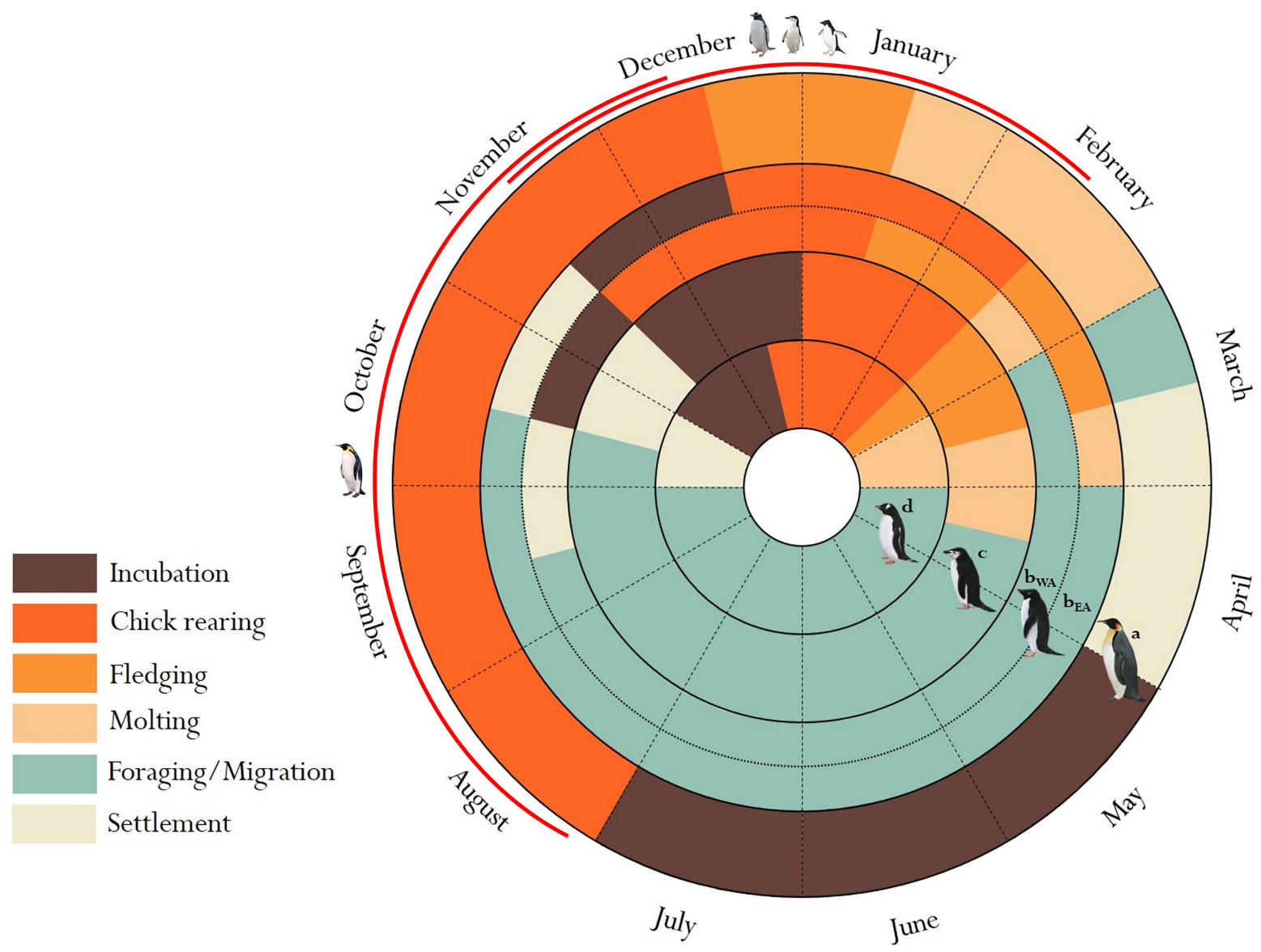

FIGURE 1 | Adult penguin life cycles of the four species of penguin breeding in Antarctica: Emperor (a), Adélie - West Antarctica (bwa), Adélie - East Antarctica $\left(b_{E A}\right)$, Chinstrap (c) and Gentoo (d) penguin, and key chick-rearing months when species have the most restricted range (red); the period for which marines IBAs were identified. Figure adapted from Emmerson et al. (2011), Lynch et al. (2012), Borboroglu and Boersma (2013), Black (2016). The figure is based on the most common reports for mainland Antarctica but variations in the start of laying dates (some of which are linked to latitude) have been observed for species by up to 2 weeks (Ainley, 2002; Emmerson et al., 2011; Black, 2016; Youngflesh et al., 2017).

\section{Delineating Marine IBAs for Antarctic Penguins}

Delineating marine IBAs for marine predators at sea requires the identification of representative core areas used by a threshold number of individuals from a population (Lascelles et al., 2016). Therefore, colony and global population estimates, and colony specific at-sea distribution data (or estimates thereof) are required.

\section{Population Estimates}

We derived abundance estimates for penguins breeding in Antarctica primarily from published sources (Supplementary Appendix: Population estimates). We focus on the number of breeding pairs as this is a primary metric for monitoring penguin population sizes. We collated the majority of abundance estimates and colony location data for penguin species via the MAPPPD data portal (updated on 02, April, 2019), a database designed for the collation of Antarctic penguin population monitoring data (Humphries et al., 2017). Notably, colonies in this data portal are categorized as those areas that represent one biologically relevant population. We supplemented this dataset with additional colony information and abundance estimates based on recent global reviews for Emperor Penguins (Wienecke, 2012; Ancel et al., 2017; Trathan et al., 2019) and Chinstrap Penguins (Strycker et al., 2020). For a minority of colonies where either nest or chick counts were provided only, we followed previous approaches to convert these estimates to number of breeding pairs (Che-Castaldo et al., 2017, Supplementary Appendix: Refinements to population estimates). The final number of colonies considered for each species was 280 for Adélie Penguins, 326 for Chinstrap Penguins, 108 for Gentoo Penguins and 54 for Emperor Penguins (Supplementary Appendix: Colony Codes).

\section{Determining At-Sea Distribution}

Collecting representative tracking data from breeding colonies within the vicinity of the study area is often not feasible - even for the key colonies in a species 


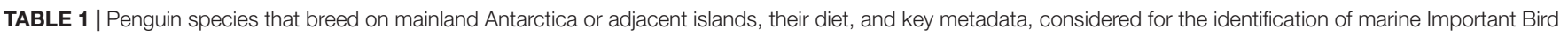
and Biodiversity Areas in Antarctica.

\begin{tabular}{|c|c|c|c|c|c|c|}
\hline Species & $\begin{array}{l}\text { IUCN Red List } \\
\text { Status }\end{array}$ & $\begin{array}{c}\text { CCAMLR } \\
\text { subareas with } \\
\text { colonies }\end{array}$ & $\begin{array}{l}\text { MPA Planning } \\
\text { Domains with } \\
\text { colonies }\end{array}$ & $\begin{array}{c}\text { Global } \\
\text { population } \\
\text { (Breeding pairs) }\end{array}$ & $\begin{array}{l}\text { Number of colonies within } \\
\text { study area used for marine } \\
\text { IBA assessment }\end{array}$ & Diet (Ratcliffe and Trathan, 2011) \\
\hline Adélie & LC & $\begin{array}{c}48.1,48.2 \\
58.4 .1,58.4 .2 \\
88.1,88.2 \\
88.3\end{array}$ & $1,3,7,8$, and 9 & $\begin{array}{l}\text { 3,790,000 (Lynch } \\
\text { and LaRue, 2014) }\end{array}$ & 280 & $\begin{array}{l}\text { Primarily euphausiid crustaceans and } \\
\text { fish: } \\
\text { Euphausia crystallorophias (crystal krill) } \\
\text { Euphausia superba (Antarctic krill) } \\
\text { Pleuragramma antarctica (Antarctic } \\
\text { silverfish) }\end{array}$ \\
\hline Chinstrap & LC & $\begin{array}{l}48.1,48.2 \\
\quad 88.1\end{array}$ & 1,8 & $\begin{array}{l}\text { 3,420,000 } \\
\text { (Strycker et al., } \\
\text { 2020) }\end{array}$ & 326 & $\begin{array}{l}\text { Primarily euphausiid crustaceans: } \\
\text { Euphausia superba (Antarctic krill) }\end{array}$ \\
\hline \multirow[t]{4}{*}{ Gentoo } & LC & $48.1,48.2$ & 1 & $\begin{array}{l}\text { 387,000 (Lynch, } \\
\text { 2013) }\end{array}$ & 108 & $\begin{array}{l}\text { Short foraging ranges for this species } \\
\text { can result in fine scale variation in diet, } \\
\text { which includes: }\end{array}$ \\
\hline & & & & & & Euphausia superba (Antarctic krill) \\
\hline & & & & & & $\begin{array}{l}\text { Pleuragramma antarctica (Antarctic } \\
\text { silverfish) }\end{array}$ \\
\hline & & & & & & Nototheniid fish \\
\hline Emperor & NT & $\begin{array}{c}48.1,48.5 \\
48.6 \\
58.4 .1,58.4 .2 \\
88.1,88.2 \\
88.3\end{array}$ & $\begin{array}{l}1,3,4,7,8 \\
\text { and } 9\end{array}$ & $\begin{array}{c}\text { 256,500 (Fretwell } \\
\text { et al., 2012; } \\
\text { Trathan et al., } \\
\text { 2019) }\end{array}$ & 54 & $\begin{array}{l}\text { Winter diet, mostly krill: } \\
\text { Euphausia superba (Antarctic krill) } \\
\text { Summer diet, mostly fish and squid: } \\
\text { Pleuragramma antarctica (Antarctic } \\
\text { silverfish) } \\
\text { Psychroteuthis glacialis (Glacial squid) }\end{array}$ \\
\hline
\end{tabular}

LC, least concern; NT, near threatened.

range - and will likely remain so for many penguin colonies in Antarctica. Therefore, alternate solutions to direct observation of distribution patterns, such as atsea surveys or individual level tracking (e.g., Carroll et al., 2019), are required.

Several methodologies for estimating seabird at-sea distribution in un-sampled regions have been proposed (Franklin, 2010; Grecian et al., 2012; Thaxter et al., 2012; Grimm et al., 2016; Soanes et al., 2016; Wakefield et al., 2017; Warwick-Evans et al., 2017, 2018; Zhang et al., 2017; Critchley et al., 2018, 2019; Dias et al., 2018b; Supplementary Appendix: Determining at-sea distribution). Determining which method is most appropriate to derive species at-sea distributions should be considered in the context of available data for a given species and its typical foraging ecology (Cleasby et al., 2018; Oppel et al., 2018; Bolton et al., 2019). For relatively short ranging species such as penguins during the breeding period (Oppel et al., 2018) - recent evidence shows that the foraging radius approach with a decay function coupled to population estimates can be a useful and pragmatic approach for assessing distributions; particularly in data sparse regions where studies involving the direct tracking of species has been limited (Critchley et al., 2018, 2019). This method involves estimating the distribution of seabirds from a source colony out to a specified buffer distance, and gives preferential weighting to those cells closest to the colony. Therefore, we built upon the method outlined in Critchley et al. (2018) to map the distribution (on a $5 \mathrm{~km} \times 5 \mathrm{~km}$ grid) and estimate the abundance of penguins at sea from individual colonies during the chick rearing period.
We specified a buffer around each colony that accounts for travel around landmasses, and weights cells closest to the colony via an inverse log function. Given the typically short-ranging movements undertaken by the penguin species compared to volant seabird species (Oppel et al., 2018), we also specified a bearing for each colony that directed birds directly away from the colony of origin. A 60 degree buffer was specified on either side of this bearing which constrained birds to forward movement away from the colonies only. The weighting of cells means that cells closest to a breeding colony represent those cells likely used by a higher percentage of the population (Supplementary Appendix: Density distribution surfaces - methods). For each species, the maximum potential radius of the buffer specified around colonies was adjusted according to CCAMLR subareas and represents the weighted mean of maximum travel distances during the critical chickrearing period of the breeding cycle, when birds typically have the most constrained foraging range (Supplementary Appendix: Literature review - foraging radii). Division by CCAMLR subareas allowed for alignment across areas with similar ecosystem characteristics and accounting for spatial heterogeneity. Foraging range distances were obtained through a comprehensive literature review identifying all colonies where tracking of penguins had occurred via GPS or platform terminal transmitter (PTT) devices (Supplementary Appendix: Literature review - foraging radii).

Given the differences in census efforts at each colony we derived density distribution surfaces for each species and their respective colonies based on four population estimates 


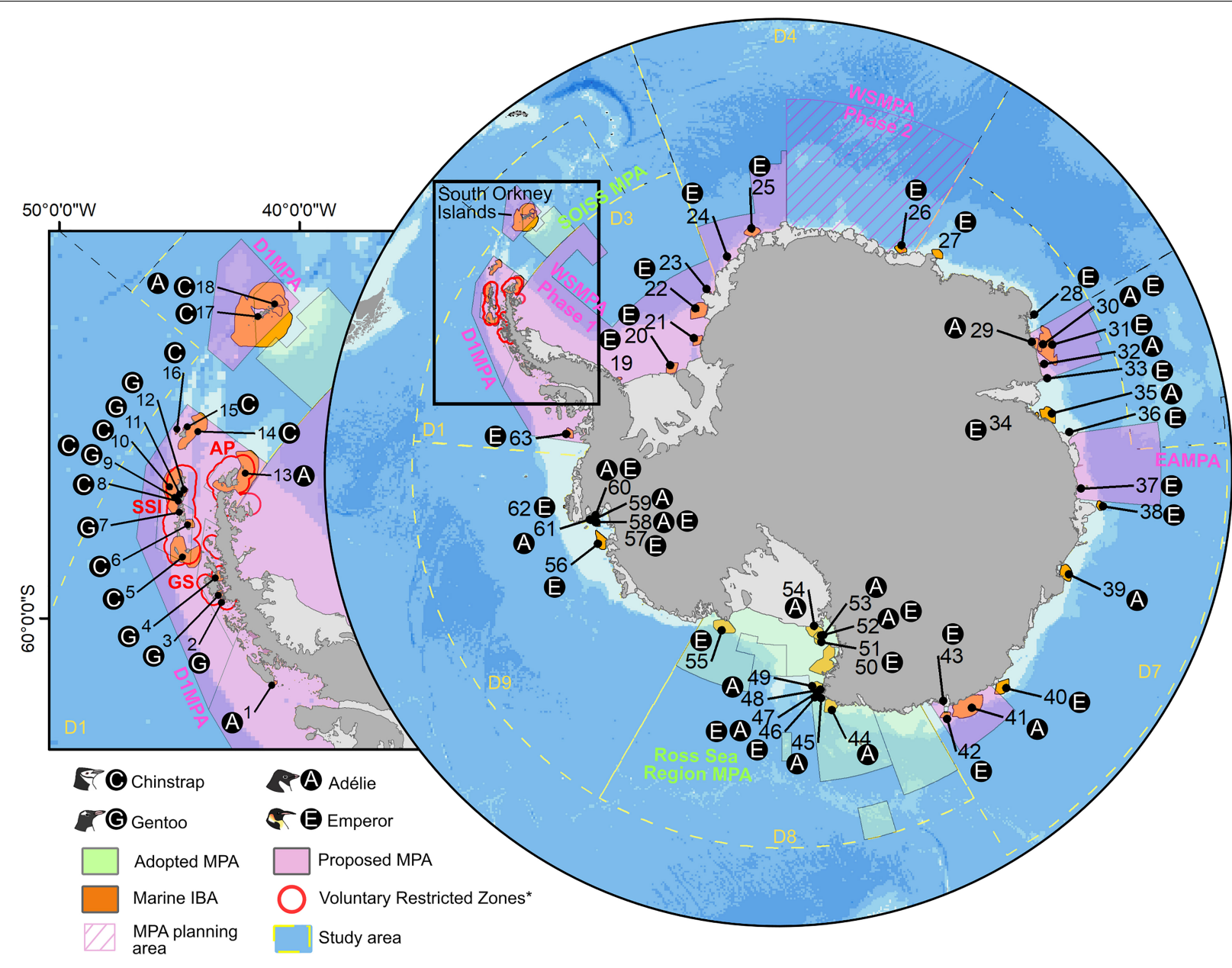

FIGURE 2 | Adopted MPAs, proposed MPAs and MPA planning area (see Supplementary Appendix - Study area and key spatial data for additional details) within the study area (CCAMLR MPA planning domains (D) 1, 3, 4, 7, 8, and 9), and overlap with identified network of 63 marine IBAs for penguin species. Text black circles adjacent to marine IBAs indicate species present within the marine IBA. Adopted MPAs within the planning domains include, the Ross Sea Region MPA and the South Orkney Islands Southern Shelf MPA (SOISS MPA). Proposed MPAs include the Domain 1 MPA (D1MPA), Weddell Sea MPA Phase 1 (WSMPA Phase 1) and the East Antarctica MPA (EAMPA). Also shown are the Weddell Sea MPA Phase 2 Planning Area (WSMPA Phase 2) and the Voluntary Restricted Zones (VRZs) in which a majority of krill fishing fleets have limited their operations in certain regions during parts of the summer (AP, antarctic peninsula: 1 Oct - 1 Feb, GS, gerlache strait: 15 Oct - 15 Feb, SSI, south shetland Islands: 1 Nov - 1 Mar). Inset map area indicated by black bounding box.

determined from the aggregated dataset: minimum, median, maximum and most recent number of breeding pairs at a given colony. This is a pragmatic choice on our part to account for the varied availability of population estimates from colonies (seldom collected in consecutive years from many colonies) when delineating marine IBA boundaries that acknowledges uncertainties with specific population estimates from individual colonies (Croxall and Kirkwood, 1979; Southwell et al., 2013; Lynch and LaRue, 2014, Supplementary Appendix: Density distribution surfaces - methods). The density distribution surfaces from each colony were then summed; providing an Antarctic-wide estimate of each species likely distribution at sea that accounts for potential geographic structuring between species breeding colonies (Santora et al., 2020). For each layer derived, we selected only those cells which had $>1 \%$ of the global population (IBA criteria A4). Then, for each species, we selected only those cells which triggered IBA criteria for at least three of four population estimates (i.e., cells had to have $>1 \%$ of the global population for at least the median, maximum and most recent counts, see Supplementary Appendix). To account for winter sea-ice distribution, final marine IBA boundaries specific to Emperor Penguins were further considered in the context of the average position of Antarctic polynyas; areas of open water surrounded by sea ice that are maintained throughout the year (Arrigo et al., 2015).

Once marine IBAs were identified at the species level, the final layers for each species were then aggregated to delineate Antarctic-wide marine IBA boundaries for all penguin species. These boundaries distinguished between marine IBAs specific to a single species, versus marine IBAs specific to two or more species. To avoid the cell based nature of areas through the identification process and delineate practicable management 
units, the final marine IBAs were converted to polygons which were further smoothed using Gaussian kernel regression, where the bandwidth was set according to the number of vertices in each polygon (Strimas-Mackey, 2018) (Supplementary Appendix: Density distribution surfaces - methods).

\section{Assessing Marine IBA Overlap With Key Management Areas}

To assess the overlap of marine IBAs with key management areas, we calculated the percentage area of marine IBAs within each of the relevant management areas. We performed this analysis separately for the VRZs and proposed MPA areas as the D1MPA and WSMPA P1 encompass the entirety of the VRZs. We also estimated the regional percentage of breeding pairs that would likely benefit from suitable conservation measures being applied to each marine IBA by summing the population estimates from each of the colonies contributing to the delineation of specific marine IBAs that overlapped relevant MPAs or VRZs.

\section{Overlap of Krill Fisheries With Marine IBAs}

We obtained data on krill catches (received from CCAMLR on 27 December 2019) in $1^{\circ}$ latitude $\times 2^{\circ}$ longitude cells at monthly intervals within the CCAMLR region spanning approximately 50 years: 1972 - 2019 (CCAMLR, 2018a). Following the approach used by Hindell et al. (2020) to assess areas against gridded "potential threat" data, we investigated the spatial distribution of the fishery in relation to the marine IBAs and addressed whether or not a disproportionate amount of krill biomass was caught within or beyond the bounds of marine IBAs. We summarized data into decadal periods (1970s, 1980s, 1990s, 2000s, and 2010s) and summed catch data (tonnes per cell) over the summer period (October-March, when the majority of krill feeding penguins are breeding) to determine the cumulative catch per cell within our study area. We compared the values of cumulative biomass caught in the marine IBA cells versus outside cells using two-tailed random permutation tests with 10,000 permutations (Hothorn et al., 2008). The null hypothesis was that the cumulative biomass caught per cell inside and outside marine IBAs would be from the same distribution.

\section{RESULTS}

\section{Marine IBAs for Antarctic Penguin Species}

Through our conservative approach, whereby cells for each species had to likely be used by $>1 \%$ of the global population for at least three of four of the population estimates used to generate the at-sea density distribution surfaces (Supplementary Appendix: Density distribution surfaces), we identified 63 marine IBAs for the four penguin species across Antarctica (Figure 2 For details of individual marine IBAs see, Supplementary Appendix: Inventory - Antarctica marine IBAs). These marine IBAs ranged across all CCAMLR subareas and MPA Planning Domains within our study area (Figure 2).
The largest percentage of marine IBAs - by area - occurred within Domain 7, while Domain 9 had the smallest proportion. For individual species, the largest percentage of marine IBAs by area - occurred in Domain 7 (Adélie and Emperor Penguins) and Domain 1 (Chinstrap and Gentoo Penguins, Table 2).

\section{Overlap of Marine IBAs and Key Management Areas}

The current CCAMLR adopted MPA network within MPA planning domains contiguous to mainland Antarctica overlaps with $23.2 \%$ of the identified marine IBAs. When considering the voluntary Restricted Zones (VRZs) along the Antarctic Peninsula, overlap with a key management area increases this percentage to $30.4 \%$. Moreover, when accounting for all adopted MPAs, VRZs and the proposed MPAs and MPA planning area, $80.5 \%$ of the marine IBAs overlap with key management areas (Figure 2 and Table 3).

Marine IBAs related to Adélie and Emperor Penguins had the greatest overlap with the adopted MPAs, while marine IBAs for Chinstrap and Gentoo Penguin have a negligible overlap (Figure 2 and Table 3). For all pygoscelid species, the VRZs extend the area of overlap for marine IBAs with a management unit by $7.2,23.8$, and $100 \%$, for Adélie, Chinstrap and Gentoo Penguins, respectively (Table 3). Similarly, when considering both the adopted and proposed MPA network and the MPA planning area (areas that completely encompass the VRZs), the overlap between marine IBAs for all species and areas increases by 49, 50.9, 88.8, and 100\% for Emperor, Adélie, Chinstrap and Gentoo Penguins, respectively, compared to the adopted MPA network alone (Table 3).

Regarding specific MPAs, the proposed MPA for East Antarctica (EAMPA) overlaps with the largest percentage of the marine IBA network, followed by the adopted Ross Sea Region MPA and proposed D1MPA; although percentage cover is largely similar for all three MPAs (Table 4). There is negligible overlap with the adopted South Orkney Islands Southern Shelf MPA and any of the marine IBAs. The largest percentage of overlap for species-specific marine IBAs within unique MPAs occurred with the Ross Sea Region MPA and East Antarctic MPA for Adélie and Emperor Penguins. The proposed D1MPA overlaps with the majority of marine IBAs for Chinstrap Penguins and all of those for Gentoo Penguins (Table 4). If all adopted and proposed MPAs were implemented, marine IBAs specific to Adélie Penguins would have the largest percentage area not encompassed by any MPA boundary (non-MPA region), followed by Emperor, Chinstrap and Gentoo Penguins, respectively (Table 4 ).

\section{Regional Abundance Estimates and Contribution of Penguin Colonies to Each Marine IBA Within MPAs and VRZs}

For Chinstrap, Gentoo and Emperor Penguins, the highest percentage of their regional population contributing to marine IBAs within specific MPAs remains the same as the percentage area overlap of marine IBAs within specific MPAs. That is, 
TABLE 2 | Percentage of marine IBAs in each of the MPA planning domains within given study area only.

\begin{tabular}{|c|c|c|c|c|c|}
\hline Domain & All mIBAs & Adélie mIBAs & Chinstrap mIBAs & Gentoo mIBAs & Emperor mIBAs \\
\hline 1 (Western Peninsula - South Scotia Arc) & $14.2 \%$ & $12.2 \%$ & $100 \%$ & $100 \%$ & $2.17 \%$ \\
\hline 3 (Weddell Sea) & $10.3 \%$ & $0.8 \%$ & $d n b$ & dnb & $16.5 \%$ \\
\hline 4 (Bouvet - Maud) & $5.04 \%$ & dnb & dnb & dnb & $8.3 \%$ \\
\hline 7 (Eastern Antarctica) & $38.3 \%$ & $54.8 \%$ & dnb & dnb & $34.1 \%$ \\
\hline 8 (Ross Sea) & $27.2 \%$ & $30.3 \%$ & $0 \%$ & dnb & $31.4 \%$ \\
\hline 9 (Amundsen - Bellingshausen) & $4.9 \%$ & $1.92 \%$ & dnb & dnb & $7.53 \%$ \\
\hline
\end{tabular}

dnb: Species does not breed in vicinity of the MPA planning domain.

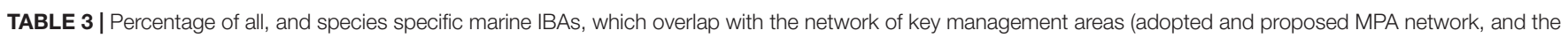
Voluntary Restricted Zones) considered within the study area (MPA planning domains 1, 3, 4, 7, 8, and 9).

\begin{tabular}{|c|c|c|c|}
\hline Species & All adopted MPAs only & All adopted MPAs and Voluntary Restricted Zones & All adopted and proposed MPAs \\
\hline All & $23.2 \%$ & $30.4 \%$ & $80.5 \%$ \\
\hline ADP: Adélie & $26.8 \%$ & $34.0 \%$ & $77.7 \%$ \\
\hline CHP: Chinstrap & $0.9 \%$ & $24.7 \%$ & $89.7 \%$ \\
\hline GEP: Gento & $0 \%$ & $100 \%$ & $100 \%$ \\
\hline EMP: Emperor & $30.7 \%$ & $30.7 \%$ & $79.7 \%$ \\
\hline
\end{tabular}

TABLE 4 | Percentage of marine IBAs in each of the specific MPAs within the study area (see Figure 2 for details).

\begin{tabular}{|c|c|c|c|c|c|}
\hline MPA & All mIBAs & Adélie mIBAs & Chinstrap mIBAs & Gentoo mIBAs & Emperor mIBAs \\
\hline D1MPA (Proposed) & $21.3 \%$ & $12.4 \%$ & $88.8 \%$ & $100 \%$ & $2.4 \%$ \\
\hline EAMPA (Proposed) & $23.2 \%$ & $38.5 \%$ & dnb & dnb & $21.6 \%$ \\
\hline WSMPA Phase 1 (Proposed) & $11.3 \%$ & $<1 \%$ & dnb & dnb & $22.1 \%$ \\
\hline WSMPA Phase 2 (Planning domain) & $1.57 \%$ & dnb & dnb & dnb & $3.1 \%$ \\
\hline Ross Sea Region MPA (Adopted) & $23.0 \%$ & $26.7 \%$ & dnb & dnb & $30.7 \%$ \\
\hline South Orkney Islands Southern Shelf MPA (Adopted) & $<1 \%$ & $0 \%$ & $<1 \%$ & $0 \%$ & dnb \\
\hline $\begin{array}{l}\text { Percentage marine IBA area not in MPA boundary (if all were } \\
\text { implemented) }\end{array}$ & $19.5 \%$ & $22.3 \%$ & $10.3 \%$ & $0 \%$ & $20.1 \%$ \\
\hline
\end{tabular}

dnb: Species does not breed within MPA.

the highest proportion of their regional populations contribute to marine IBAs within the proposed D1MPA for Chinstrap and Gentoo Penguins, and the Ross Sea Region MPA for Emperor Penguins. However, for Adélie Penguins, while the largest percentage of overlap between marine IBAs and MPAs for these species occurred within the proposed East Antarctica MPA (EAMPA), the highest proportion of their regional population also contributed to marine IBAs within the proposed D1MPA (Table 5).

\section{Overlap of Krill Fisheries With Marine IBAs}

Within MPA planning domains contiguous to mainland Antarctica, the krill fishery has moved over the past five decades from having a dispersed and largely circumpolar fishing effort to a concentrated fishing effort in the South Atlantic sector, which includes areas around the Antarctic Peninsula (Figure 3 and Supplementary Appendix: Overlap of krill fisheries with marine IBAs). In all decades within the study area (1970s, 1980s, 1990s, 2000s, and 2010s), there was a higher proportion of cells with krill catches inside marine IBAs versus outside (Figure 3: panels i inset, and Supplementary Appendix: Overlap of krill fisheries with marine IBAs). Furthermore, based on the two twotailed random permutation test, krill catches per cell were significantly different inside versus outside marine IBAs (1970s - 2010s: $p$-value $<0.001, \mathrm{Z}$-score $<-5$, Supplementary Appendix: Overlap of krill fisheries with marine IBAs) with cumulative krill biomass caught being higher inside of marine IBAs compared to outside marine IBAs for all decades (Figure 3: panels ii inset). The reduced range that the contemporary krill fishery operates over means that less fishing is now occurring beyond the boundaries of marine IBAs and is instead concentrated in focal marine IBAs along the Antarctic Peninsula and nearby islands; particularly the South Orkney Islands where the highest cumulative krill biomass catches across all decades have been recorded in the 2010s [Figure 3, panel b(ii)].

Regarding specific management units in relation to the marine IBAs and krill fisheries, high krill biomass catches were most prevalent in MPA planning domains 7 (EAMPA) and 1 (D1MPA). Within these domains, high krill biomass catches were concentrated within particular zones of the EAMPA and D1MPA. Between 4 and 15 marine IBAs were located within these 
TABLE 5 | Marine IBA overlap with key management areas in waters surrounding Antarctica (see Figure 2 for details), including the number of colonies that contributed to the given marine IBA (based on the density distributions produced for each colony: see section "Materials and Methods").

\begin{tabular}{|c|c|c|c|c|c|c|}
\hline & & All mIBAs & Adélie mIBAs & Chinstrap mIBAs & Gentoo mIBAs & Emperor mIBAs \\
\hline \multirow[t]{4}{*}{ D1MPA (Proposed) } & mIBA code & $1-18,63$ & $1,13,18$ & $\begin{array}{c}5,6,8-10 \\
14-18\end{array}$ & $2-4,7,9,11,12$ & 63 \\
\hline & Number of colonies & 364 & 55 & 252 & 56 & 1 \\
\hline & \% Regional pop. to mIBA (lower) & - & $22 \%$ & $78 \%$ & $30 \%$ & $2.01 \%$ \\
\hline & $\%$ Regional pop. to mIBA (upper) & - & $34 \%$ & $97 \%$ & $73 \%$ & $2.01 \%$ \\
\hline \multirow[t]{4}{*}{ EAMPA (Proposed) } & mIBA code & $\begin{array}{c}29-33,37,38 \\
40-43\end{array}$ & $29,30,32,41$ & dnb & dnb & $\begin{array}{c}30,31,33,37,38 \\
40,42,43\end{array}$ \\
\hline & Number of colonies & 51 & 41 & dnb & dnb & 10 \\
\hline & $\%$ Regional pop. to mIBA (lower) & - & $10 \%$ & dnb & $d n b$ & $15 \%$ \\
\hline & $\%$ Regional pop. to mIBA (upper) & - & $12 \%$ & $d n b$ & $d n b$ & $22 \%$ \\
\hline \multirow[t]{4}{*}{ WSMPA Phase 1 (Proposed) } & mIBA code & $13,19-25$ & 13 & dnb & dnb & $19-25$ \\
\hline & Number of colonies & 8 & $\mathrm{ng}$ & dnb & dnb & 8 \\
\hline & $\%$ Regional pop. to mIBA (lower) & - & $\mathrm{ng}$ & dnb & dnb & $20 \%$ \\
\hline & $\%$ Regional pop. to mIBA (upper) & - & ng & dnb & dnb & $21 \%$ \\
\hline \multirow[t]{4}{*}{ WSMPA Phase 2 (Proposed) } & mIBA code & 26 & $d n b$ & dnb & dnb & 26 \\
\hline & Number of colonies & 1 & $d n b$ & dnb & dnb & 1 \\
\hline & \% Regional pop. to mIBA (lower) & - & dnb & dnb & dnb & $2 \%$ \\
\hline & $\%$ Regional pop. to mIBA (upper) & - & dnb & dnb & dnb & $2 \%$ \\
\hline \multirow[t]{4}{*}{ RSRMPA (Adopted) } & mIBA code & $44-55$ & $\begin{array}{c}44,45,47-49 \\
52-54\end{array}$ & dnb & dnb & $46,47,50-52,55$ \\
\hline & Number of colonies & 31 & 24 & dnb & dnb & 7 \\
\hline & \% Regional pop. to mIBA (lower) & - & $10 \%$ & $d n b$ & $d n b$ & $12 \%$ \\
\hline & $\%$ Regional pop. to mIBA (upper) & - & $29 \%$ & dnb & dnb & $32 \%$ \\
\hline SOISS MPA (Adopted) & $\begin{array}{l}- \\
-\end{array}$ & & & & & \\
\hline \multirow[t]{4}{*}{ VRZs } & mIBA code & $5-13$ & 13 & $5,6,8,9,10$ & $7,9,11,12$ & dnb \\
\hline & Number of colonies & 203 & 29 & 118 & 56 & dnb \\
\hline & \% Regional pop. to mIBA (lower) & - & $18 \%$ & $37 \%$ & $30 \%$ & dnb \\
\hline & $\%$ Regional pop. to mIBA (upper) & - & $27 \%$ & $55 \%$ & $72 \%$ & $\mathrm{dnb}$ \\
\hline
\end{tabular}

Percentage of regional population estimate indicates the percentage of the population from the study area that contributed to the marine IBAs overlapping relevant MPAs. Lower and upper estimates were assessed against the summed total maximum population estimates from colonies, respectively. mIBA, Marine IBA; ng, Negligible proportion (<1\%) of marine IBAs overlap with MPA planning domain; dnb, Species does not breed within MPA. 

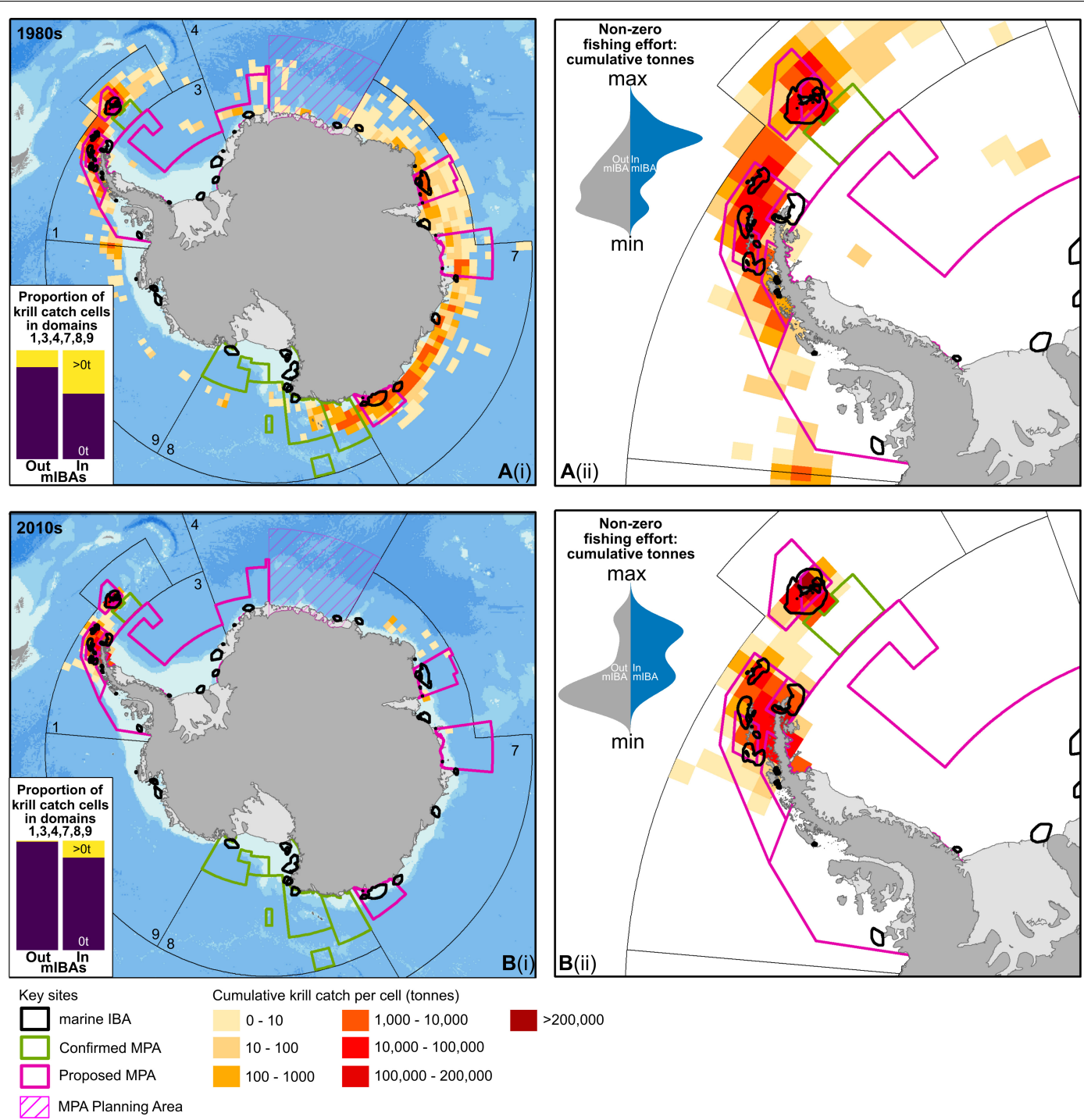

$>200,000$

FIGURE 3 | Summer krill fishing effort (Oct - Mar) for past (A: 1980) and current decades (B: 2010) across the study area; MPA planning domains contiguous to mainland Antarctica (Domains: 1, 3, 4, 7, 8, and 9). Fishing effort recorded as cumulative krill biomass caught per cell (tonnes). Panels i, indicate continent wide fishing effort across relevant domains, while panels ii, indicate fishing effort for the Antarctic Peninsula. Inset in panels $i$, indicates proportions of cells inside and outside marine IBAs in which krill was caught (>0t, yellow) or not caught (Ot, purple). Inset in panels ii (kernel density plots), show the distribution of cumulative krill biomass caught per cell (zero values not shown) inside (blue) versus outside (gray) marine IBAs. The scale for kernel density plots ranges between the minimum and maximum krill biomass caught per cell in a given decade. For all decades, see Supplementary Appendix: Overlap of krill fisheries with marine IBAs.

TABLE 6 | Key MPA management units and species of relevance in relation to the marine IBAs and krill fisheries operations within the study area where high krill biomass catches occurred per decade.

\begin{tabular}{|c|c|c|c|c|}
\hline Decade & MPA Planning domains & Specific MPAs & Specific marine IBAs with high krill catches & Key species \\
\hline 1980s & 1 & D1MPA & $2-12,14-18$ & ADP, CHP, GEP \\
\hline \multirow[t]{2}{*}{ 1990s } & 1 & D1MPA & $3-18$ & ADP, CHP, GEP \\
\hline & 7 & - & & \\
\hline $2000 s$ & 1 & D1MPA & $3-15,17,18$ & ADP, CHP, GEP \\
\hline
\end{tabular}

Study area is bound by CCAMLR MPA planning domains 1, 3, 4, 7, 8, and 9. See Figure 2 for details. Key species codes: ADP (Adélie), CHP (Chinstrap), GEP (Gentoo), EMP (Emperor). 
respective regions, with all four species present in these marine IBAs (Table 6).

\section{DISCUSSION}

While a number of global initiatives have called for various percentage-based targets in terms of protected areas in the marine environment, a critical and central objective is also to conserve important high-quality marine sites of either national or international biodiversity value. Therefore, it is clear that percentage-based targets will need to be evaluated according to the system in question (Visconti et al., 2019). Here, we have provided critical evidence of the location and relevance of some of the most important areas - marine IBAs - for chick-rearing adult penguins breeding in Antarctica and the surrounding nearby islands. Considering penguins are some of the most conspicuous wildlife in Antarctica, and among other seabirds have often been regarded as sentinels of the marine environment (Boersma, 2008; Gagne et al., 2018; Hazen et al., 2019; Velarde et al., 2019), these data provide valuable evidence toward the ongoing discussions regarding marine protected area delineation in Antarctica (CCAMLR, 2019a,b,c; Chown and Brooks, 2019; Brooks et al., 2020). Specifically, our data show that within CCAMLR MPA planning domains $1,3,4,7,8$, and 9 , there are marine areas that meet criteria to be identified as marine IBAs for all four penguin species. Furthermore, with the adoption of the three proposed MPAs and potentially a fourth within these domains, the areas in which some of the most important global sites for chick-rearing adult penguins could be protected or have more effective management regulations in place would increase by between 49 to $100 \%$ depending on the species.

In light of anthropogenic pressures on the Antarctic marine system, adoption of all MPAs could mean valuable increases in conservation and management measures for penguin populations considering that the two MPAs currently adopted in the study region only encompass between 0 and $30.7 \%$ of marine IBAs, depending on the species. This result can in part be explained by the fact that designation of the South Orkney Islands Southern Shelf MPA only considered post-breeding penguin tracking data (Trathan and Grant, 2019; Warwick-Evans et al., 2019). Furthermore, one must also consider that the adopted and proposed MPAs were not solely designed for breeding adult penguins, but numerous other Antarctic taxa at many different times of year (CCAMLR, 2009, 2016, 2019a,b; Trathan and Grant, 2019; Brooks et al., 2020; Sylvester and Brooks, 2020; Teschke et al., 2020). Decisions regarding the adoption of proposed MPAs must account for the full suite of available data, of which the marine IBAs now offer a valuable contribution. In doing so, this will serve toward an overarching vision of CCAMLR, as a key aim is to achieve an ecosystem-wide approach to management that should consider fisheries target species in conjunction with the predators that rely on these species too (CCAMLR, 2018b).

Through the protection or enhanced management of the identified marine IBAs via the proposed and currently adopted network of MPAs in Antarctica, other multi-taxa studies further highlight the likely benefits these MPAs could bring.
These include greater representation of 17 benthic and pelagic ecoregions (out of 23 and 19, respectively) in the MPA network, regions that host unique sets of species communities (Brooks et al., 2020). Numerous other Antarctic marine top predators including seals, petrels and whales primarily use sites identified as "areas of ecological significance" in the same areas that marine IBAs were identified. These areas are also in the D1MPA along the West Antarctic Peninsula, Weddell Sea MPA Phase 1 and 2, EAMPA in East Antarctica and the Ross Sea Region MPA in the Ross Sea (Hindell et al., 2020). Furthermore, global mapping initiatives that have either collated multiple evidence streams of where species require protection or management (Gownaris et al., 2019; Zhao et al., 2020), or which have looked at the costbenefit analysis of MPAs (Brander et al., 2020; Klein and Watters, 2020b), also recognize the Antarctic Peninsula, Weddell Sea and East Antarctica as being places that fall outside the bounds of adopted MPAs and that could benefit from protection afforded by well-designed MPAs in the regions.

The marine IBAs for penguins along the Antarctic Peninsula and the nearby South Shetland and South Orkney Islands are in areas where some of the largest krill catches have been taken (Figure 3). This aligns with our data showing that despite a generally contracted range of operation by the krill fishery in Antarctica over the past five decades, there is consistently a disproportionate amount of krill being harvested within marine IBAs compared to the total area the fishery operates. Therefore, our results reinforce the fact that contemporary krill fisheries may be directly competing with pygoscelid penguin populations for one of their primary prey resources (Hinke et al., 2017; Trathan et al., 2018; Watters et al., 2020). To a certain extent the VRZs, which are adhered to during certain times of year by certain fleets, do mitigate the likelihood of many krill fishing vessels overlapping with marine IBAs for Gentoo Penguins and some Chinstrap and Adélie Penguin populations (Table 3). However, at the South Orkney Islands where there are no additional conservation measures such as the VRZs, the marine IBAs for Adélie and Chinstrap Penguins overlap with the area where the greatest amount of krill has been caught during the summer chick-rearing period (Figure 3). Therefore, competition for food resources could become critical.

This competition for food resources may be especially relevant for the Adélie Penguins, as they are the ice-obligate pygoscelid species that most likely face the largest threat from climate change too (Forcada and Trathan, 2009; Lyver et al., 2014; CheCastaldo et al., 2017). This means that within the proposed D1MPA - which hosts some of the largest regional proportions of Adélie and Chinstrap Penguin populations contributing to the identified marine IBAs - continued evaluation should be sought to mitigate the potentially negative consequences that numerous other species are facing due to overexploitation of resources (Maxwell et al., 2016; Klein and Watters, 2020b). Beyond the bounds of the planning domain for the D1MPA, our results highlight that past krill fishery operations had some of the largest krill catches overlapping with marine IBAs in East Antarctica and that the krill fishery is expanding in this region again; as recognized by others (Nicol and Foster, 2016; Chown and Brooks, 2019). This underscores the need for implementing appropriate 
conservation and management measures to avoid the added pressure that krill fisheries could place on penguins during the critical chick-rearing period should the fisheries begin regularly operating in these areas again.

The krill fishery, along with the growing challenges of pollution, and human intrusion and disturbance, are likely to be the most site specific pressures penguins will face at particular marine IBAs (Trathan et al., 2014; Dias et al., 2019; RopertCoudert et al., 2019). Additionally, climate change is a key pervasive pressure that all penguin species face in marine IBAs across Antarctica (Trathan et al., 2019; Hindell et al., 2020). Forecasts from climate coupled population and distribution models show these responses for penguins and numerous other Antarctic taxa will vary depending on the region and species (Jenouvrier et al., 2019; Hindell et al., 2020; Iles et al., 2020; Rogers et al., 2020). However, the broad consensus is that the impact of climate change will be negative for the majority of species, especially those endemic to Antarctica such as the Emperor Penguin (Trathan et al., 2019; Rogers et al., 2020). The already adopted Ross Sea Region MPA offers some respite from the compounding pressures of climate change and other threats this species faces. The adoption of the proposed Weddell Sea MPA Phase 1, would offer added respite as this MPA not only hosts the second largest proportion of the species global population contributing to marine IBAs, but has also been recognized as a key refuge for the species in light of climate change (Jenouvrier et al., 2019). This supports the call for a network of site based conservation approaches for this species to alleviate the compounding effects of multiple stressors (Trathan et al., 2019).

Considering our study focuses on identifying important marine areas of global significance for adult penguins during the chick-rearing period - a key period of the year when birds are constrained to return to their specific breeding colony context-specific decisions that account for regionally important populations should also be made when aiming to achieve local, national or global goals (Smith et al., 2019). A further caveat to consider is that the size of an area to be delineated as a marine IBA will be influenced by colony population numbers that are likely to fluctuate on an annual basis owing to both variations in environmental conditions (Che-Castaldo et al., 2017; Jenouvrier et al., 2017; Iles et al., 2020), and possible emigration or immigration for some species (Ainley et al., 2004; Fretwell and Trathan, 2019). Also, seabird foraging range is typically deemed to increase for birds from larger colonies (Jovani et al., 2016), a phenomenon not directly incorporated into our approach. However, suitably accounting for both these factors at an Antarctic wide scale is unfeasible owing to irregular population monitoring at the majority of penguin breeding sites across Antarctica, and also because our literature review of tracking studies revealed that we primarily have tracking data from only the smaller colonies of Chinstrap and Gentoo Penguins. Therefore, by scaling foraging ranges according to CCAMLR subareas, weighting cells through the density decay function and including only those cells where a minimum of three count types overlapped, we highlight that the marine IBAs represent conservative average estimates of likely penguin distribution during the chick-rearing period and do not expect that areas overly represent important habitat requirements. Furthermore, as the population metric used to delineate marine IBAs was annual number of breeding pairs, these too are conservative estimates for the total number of birds which might use the areas.

While a large majority of the adult population of penguins attempt to breed each year, the distribution of juvenile birds, those that skip breeding in some years and adult birds during the non-breeding period were not specifically considered in our study. For each of these groups of birds, parts of the Antarctica Peninsula and nearby islands remain key habitat for many pygoscelid penguins (Wilson et al., 1998; Trivelpiece et al., 2007; Erdmann et al., 2011; Hinke and Trivelpiece, 2011; Hinke et al., 2019). However, as all four species are no longer constrained by the need to return to breeding colonies, birds disperse more broadly and will overlap with other CCAMLR MPAs and planning domains (Ratcliffe and Trathan, 2011; Thiebot et al., 2019; Warwick-Evans et al., 2019). In recognition of these broader dispersal patterns that are also common in other taxa utilizing the Southern Ocean (e.g., marine mammals, IUCNMMPATF, 2020), and also the potential for competition between krill fisheries and penguins in the winter, we recognize that action for the identified marine IBAs provides only a part of the holistic solution required for the conservation and management of the Antarctic marine ecosystem (Hinke et al., 2017; Carneiro et al., 2020; Hindell et al., 2020; Watters et al., 2020).

The Antarctic marine environment is one of many marine systems where the conservation and management of particular areas and species must be considered amidst a myriad of priorities (Humphreys and Clark, 2020). Numerous other MPAs, including their management frameworks, have already been designated or revised based on the best available evidence that often comes from a handful of key species (Hays et al., 2019; Javed et al., 2019). The marine IBAs we identified for penguin species in Antarctica provide conservative boundaries of perhaps some of the highest quality areas for these species globally given that they were designated as marine IBAs based on the number of aggregating birds (IBA criteria A4). Subsequently, the identification of these important areas offers guidance as to where decision makers can act (Ludynia et al., 2012; Boersma et al., 2015; Handley et al., 2020), and where appropriate management action can find alignment with the call for identifying high quality sites (Visconti et al., 2019). A specific management action relevant to the identified marine IBAs hosting these important populations of penguins, could be appropriately designed spatiotemporal closures of fisheries operations that undergo regular review processes. Such management actions have already been implemented to support not only penguin populations, but a number of other marine megafauna and the prey the depend on in other systems (GSGSSI, 2013; Cunningham et al., 2015; Sherley et al., 2015; Dawson et al., 2017; Hays et al., 2019; SANPARKS, 2020). Of course, the implications of these management actions should be considered in the context of the specific system in question. Within the proposed D1MPA area specifically, several studies have now showcased the likely impacts that localized krill fisheries are having on penguin populations (Hinke et al., 2017; Trathan et al., 2018; Krüger et al., 2020; Watters et al., 2020). However, if an MPA with 
appropriately zoned regions were implemented, this could prove beneficial for both penguin and prey populations; with authors recognizing that the implications to krill catch rates for fishers are not entirely understood (Klein and Watters, 2020a,b). This connection between the conservation of biodiversity (regionally) and the socio-economic factors to consider more broadly, highlights the complexity of actions decision makers will need to review when assessing appropriate spatiotemporal closures within MPAs (Humphreys and Clark, 2020). Therefore, to support the conservation of biodiversity while further realizing the socio-economics links inherent in such decisions (regionally and more broadly), the emerging "telecoupling" framework may serve as an alternate assessment opportunity in future (Hull et al., 2019; Rey and Huettmann, 2020).

As IBAs should be evaluated every 8-12 years (Donald et al., 2018), they also provide a critical baseline for the monitoring and evaluation of specific important areas in future; readily achievable with the framework presented in this paper. Coupled with the re-evaluation of the marine IBAs, enhanced understanding of fine scale environmental data, anthropogenic pressures and long-term population data, to assess how pressures may act in combination on a species will also be of great value. The use of remote and direct monitoring technologies such as satellite imagery (Fretwell and Trathan, 2009; Lynch et al., 2012) and timelapse cameras (Southwell and Emmerson, 2015; Hinke et al., 2018; Jones et al., 2018) will offer solutions to some of these challenges in future. This will be critical to consistently evolve our understanding of predator and ecosystem responses to growing anthropogenic stressors and potential environmental change more broadly.

Ultimately, Antarctica and its biodiversity are deemed to be facing "discernment hysteresis," whereby the lack of appreciation of evidence might - as it has elsewhere - lead to irreversible changes to the ecosystem (Maxwell et al., 2016; Chown and Brooks, 2019). The precautionary action of enhancing environmental management now, will likely support ecosystem functioning of this system in future. Therefore, not only mitigating the potential for catastrophic declines of penguin populations as has happened elsewhere (Boersma et al., 2019; Ropert-Coudert et al., 2019), but for numerous other Antarctic species too.

\section{REFERENCES}

Ainley, D. (2002). The Adélie Penguin: Bellwether of Climate Change. New York, NY: Columbia University press.

Ainley, D. G., Ribic, C. A., Ballard, G., Heath, S., Gaffney, I., Karl, B. J., et al. (2004). Geographic structure of Adélie penguin populations: overlap in colony-specific foraging areas. Ecol. Monogr. 74, 159-178. doi: 10.1890/ 02-4073

Ancel, A., Cristofari, R., Trathan, P. N., Gilbert, C., Fretwell, P. T., and Beaulieu, M. (2017). Looking for new emperor penguin colonies? Filling the gaps. Glob. Ecol. Conserv. 9, 171-179. doi: 10.1016/j.gecco.2017.01.003

Arrigo, K. R., Dijken, G. L., and Strong, A. L. (2015). Environmental controls ofmarine productivity hot spots around Antarctica. J. Geophys. Res. Ocean 120, 2813-2825. doi: 10.1002/2014JC010387

\section{DATA AVAILABILITY STATEMENT}

The original contributions presented in the study are included in the article/Supplementary Material, further inquiries can be directed to the corresponding author/s.

\section{ETHICS STATEMENT}

Ethical review and approval was not required for the animal study because study utilized publicly available data.

\section{AUTHOR CONTRIBUTIONS}

$\mathrm{JH}, \mathrm{MD}$, and PT sourced funding. JH, M-MR, KT, GG, CC, PT, and MD collated or contributed the data. JH and M-MR analyzed the data with support from all and wrote the manuscript with support from all. All authors reviewed the final manuscript and approved the submitted version.

\section{FUNDING}

Support for this project was provided by The Pew Charitable Trusts. M-MR was financially supported by the European Commission through the program Erasmus Mundus Master Course - International Master in Applied Ecology (EEMC IMAE) (FPA 2023-0224/532524-1-FR-2012-1-ERA MUNDUSEMMC) - Coordination F.-J. Richard, Université de Poitiers, France.

\section{SUPPLEMENTARY MATERIAL}

The Supplementary Material for this article can be found online at: https://www.frontiersin.org/articles/10.3389/fmars. 2020.602972/full\#supplementary-material

Supplementary Data Sheet 1 | Summarised data used for the marine IBA
analysis.

Supplementary Appendix | Marine IBAs Antarctica, background information.

Supplementary Inventory | Antarctica marine IBA inventory.

Bhola, N., Klimmek, H., Kingston, N., Burgess, N. D., Soesbergen, A., Van Corrigan, C., et al. (2020). Perspectives on area-based conservation and what it means for the post-2020 biodiversity policy agenda. Conserv. Biol. 1-11. doi: 10.1111/cobi.13509

Black, C. E. (2016). A comprehensive review of the phenology of Pygoscelis penguins. Polar Biol. 39, 405-432. doi: 10.1007/s00300-015-1807-8

Boersma, P. D. (2008). Penguins as marine sentinels. Bioscience 58, 597-607. doi: 10.1641/B580707

Boersma, P. D., Borboroglu, P. G., Gownaris, N. J., Bost, C. A., Chiaradia, A., Ellis, S., et al. (2019). Applying science to pressing conservation needs for penguins. Conserv. Biol. 34, 103-112. doi: 10.1111/cobi.13378

Boersma, P. D., Rebstock, G. A., and García-borboroglu, P. (2015). Marine protection is needed for Magellanic penguins in Argentina based on long-term data. Biol. Conserv. 182, 197-204. doi: 10.1016/j.biocon.2014.12.005 
Bolton, M., Conolly, G., Carroll, M., Wakefield, E. D., and Caldow, R. (2019). Review a review of the occurrence of inter-colony segregation of seabird foraging areas and the implications for marine environmental impact assessment. Ibis 161, 241-259. doi: 10.1111/ibi.12677

Borboroglu, P. G., and Boersma, P. D. (2013). Penguins: Natural History and Conservation. Seattle: University of Washington Press.

Brander, L. M., van Beukering, P., Nijsten, L., McVittie, A., Baulcomb, C., Eppink, F. V., et al. (2020). The global costs and benefits of expanding marine protected areas. Mar. Policy 116:103953. doi: 10.1016/j.marpol.2020.103953

Brooks, C. M. (2013). Competing values on the Antarctic high seas: CCAMLR and the challenge of marine-protected areas. Polar J. 3, 277-300. doi: 10.1080/ 2154896X.2013.854597

Brooks, C. M., Chown, S. L., Douglass, L. L., Raymond, B. P., Shaw, J. D., Sylvester, Z. T., et al. (2020). Progress towards a representative network of Southern Ocean protected areas. PLoS One 15:e0231361. doi: 10.1371/journal. pone. 0231361

Carneiro, A. P. B., Pearmain, E. J., Oppel, S., Clay, T. A., Phillips, R. A., BonnetLebrun, A. S., et al. (2020). A framework for mapping the distribution of seabirds by integrating tracking, demography and phenology. J. Appl. Ecol. 57, 514-525. doi: 10.1111/1365-2664.13568

Carroll, M. J., Wakefield, E. D., Scragg, E. S., Owen, E., Pinder, S., Bolton, M., et al. (2019). Matches and mismatches between seabird distributions estimated from at-sea surveys and concurrent individual-level tracking. Front. Ecol. Evol. 7:333. doi: $10.3389 /$ fevo.2019.00333

CBD (2010). Aichi Biodiversity Targets. Available online at: https://www.cbd.int/sp/ targets/ (accessed January 12, 2019).

CCAMLR (2009). Commission for the Conservation of Antarctic Marine Living Resources (CCAMLR). Conservation Measure 91-03. Protection of the South Orkney Islands Southern Shelf. Available online at: https://www.ccamlr.org/en/ measure-91-03-2009 (accessed August 26, 2020).

CCAMLR (2016). Commission for the Conservation of Antarctic Marine Living Resources (CCAMLR). Conservation Measure 91-05. Ross Sea Region Marine Protected Area. Available online at: https://www.ccamlr.org/en/measure-91-052016 (accessed August 26, 2020).

CCAMLR (2018a). Krill Fishery Report 2018. Hobart: CCAMLR.

CCAMLR (2018b). Text of the Convention on the Conservation of Antarctic Marine Living Resources. Available online at: https://www.ccamlr.org/en/organisation/ camlr-convention-text\#II (accessed August 26, 2020).

CCAMLR (2019a). CCAMLR-38/23. Proposal to Establish a Marine Protected Area Across the Weddell Sea Region (Phase 1). Delegation of the European Union and its Member States and Norway. Hobart: Commission for the Conservation of Antarctic Marine Living Resources.

CCAMLR (2019b). CCAMLR-38/25 Rev. 1 Revised Proposal for a Conservation Measure Establishing a Marine Protected Area in Domain 1 (Western Antarctic Peninsula and South Scotia Arc). Delegations of Argentina and Chile. Hobart: Commission for the Conservation of Antarctic Marine Living Resources.

CCAMLR (2019c). Report of the Thirty-Eighth Meeting of the Commission. Hobart: Commission for the Conservation of Antarctic Marine Living Resources.

CCRF (2018). Implementation of the 1995 FAO Code of Conduct for Responsible Fisheries - Web Sit: Code of Conduct for Responsible Fisheries, FI Institutional Websites. Rome: FAO.

Che-Castaldo, C., Jenouvrier, S., Youngflesh, C., Shoemaker, K. T., Humphries, G., McDowall, P., et al. (2017). Pan-Antarctic analysis aggregating spatial estimates of Adélie penguin abundance reveals robust dynamics despite stochastic noise. Nat. Commun. 8, 1-8. doi: 10.1038/s41467-017-00890-0

Chown, S. L., and Brooks, C. M. (2019). The state and future of antarctic environments in a global context. Annu. Rev. Environ. Resour. 44, 1-30. doi: 10.1146/annurev-environ-101718-033236

Cleasby, I. R., Owen, E., Wilson, L., and Bolton, M. (2018). Combining Habitat Modelling and Hotspot Analysis to Reveal the Location of High Density Seabird Areas Across the UK: Technical Report. RSPB Research Report no. 63. Sandy: RSPB Centre for Conservation Science, RSPB.

Critchley, E. J., Grecian, W. J., Bennison, A., Kane, A., Wischnewski, S., Cañadas, A., et al. (2019). Assessing the effectiveness of foraging radius models for seabird distributions using biotelemetry and survey data. Ecography 42, 1-13. doi: $10.1111 /$ ecog.04653

Critchley, E. J., Grecian, W. J., Kane, A., Jessopp, M. J., and Quinn, J. L. (2018). Marine protected areas show low overlap with projected distributions of seabird populations in Britain and Ireland. Biol. Conserv. 224, 309-317. doi: 10.1016/j. biocon.2018.06.007

Croll, D. A., Demer, D. A., Hewitt, R. P., Jansen, J. K., Goebel, M. E., and Tershy, B. R. (2006). Effects of variability in prey abundance on reproduction and foraging in chinstrap penguins (Pygoscelis antarctica). J. Zool. 269, 506-513. doi: 10.1111/j.1469-7998.2006.00090.x

Croxall, J. P., and Kirkwood, E. (1979). The Distribution of Penguins on the Antarctic Peninsula and Islands of the Scotia Sea. Cambridge: British Antarctic Survey.

Cunningham, S., Chaniotis, P. D., Gillham, K., and James, B. (2015). Assessment of the Adequacy of the Scottish MPA Network for MPA Search Features: Summary of the Application of Stage 5 of the MPA Selection Guidelines Post Consultation. Assessing Risk to Scottish MPA Search Features at the MPA Regional Scale. Final Report. Available online at: https://www.nature.scot/marine-protected-areaassessment-adequacy-scottish-mpa-network-mpa-search-features-summary (accessed November 15, 2020).

Dawson, T. M., Formia, A., Agamboué, P. D., Asseko, G. M., Boussamba, F., Cardiec, F., et al. (2017). Informing marine protected area designation and management for nesting olive ridley sea turtles using satellite tracking. Front. Mar. Sci. 4:312. doi: 10.3389/fmars.2017. 00312

Dias, M. P., Carneiro, A. P. B., Warwick-evans, V., Harris, C., Lorenz, K., Lascelles, B., et al. (2018a). Identification of marine important bird and biodiversity areas for penguins around the South Shetland Islands and South Orkeny Islands. Ecol. Evol. 8, 10520-10529. doi: 10.1002/ece3. 4519

Dias, M. P., Warwick-Evans, V., Carneiro, A. P. B., Harris, C., Lascelles, B. G., Clewlow, H. L., et al. (2018b). Using habitat models to identify marine important bird and biodiversity areas for Chinstrap Penguins Pygoscelis antarcticus in the South Orkney Islands. Polar Biol. 42, 17-25. doi: 10.1007/ s00300-018-2404-4

Dias, M. P., Martin, R., Pearmain, E. J., Burfield, I. J., Small, C., Phillips, R. A., et al. (2019). Threats to seabirds: a global assessment. Biol. Conserv. 237, 525-537. doi: 10.1016/j.biocon.2019.06.033

Donald, P., Fishpool, L., Leon, B., Bunting, G., Burfield, I., Butchart, S. H. M., et al. (2018). Important Bird and Biodiversity Areas (IBAs): the development and characteristics of a global inventory of key sites for biodiversity. Bird Conserv. Int. 129, 1-22. doi: 10.1017/S0959270918000102

Dudley, N. (2008). Guidelines for Applying Protected Area Management Categories. Gland: IUCN, 86. Stolton, S., P. Shadie and N. Dudley (2013). IUCN WCPA Best Practice Guidance on Recognising Protected Areas and Assigning Management Categori

Emmerson, L., Southwell, C., Clarke, J., Tierney, M., and Kerry, K. (2015). Adélie penguin response parameters signal reduced prey accessibility: implications for predator-prey response curves. Mar. Biol. 162, 1187-1200. doi: 10.1007/s00227015-2661-5

Emmerson, L. M., Pike, R., and Southwell, C. (2011). Variability in the breeding phenology of Adélie penguins: potential causes and consequences for reproductive success. Mar. Ecol. Prog. Ser. 440, 203-216.

Erdmann, E. S., Ribic, C. A., Patterson-Fraser, D. L., and Fraser, W. R. (2011). Characterization of winter foraging locations of Adélie penguins along the Western Antarctic Peninsula, 2001-2002. Deep. Res. Part II Top. Stud. Oceanogr. 58, 1710-1718. doi: 10.1016/j.dsr2.2010.10.054

Forcada, J., and Trathan, P. N. (2009). Penguin responses to climate change in the Southern Ocean. Glob. Chang. Biol. 15, 1618-1630. doi: 10.1111/j.1365-2486. 2009.01909.x

Franklin, J. (2010). Mapping Species Distribution: Spatial Inference and Prediction. Cambridge: Cambridge University Press.

Fretwell, P. T., Larue, M. A., Morin, P., Kooyman, G. L., Wienecke, B., Ratcliffe, N., et al. (2012). An emperor penguin population estimate: the first global, synoptic survey of a species from space. PLoS One 7:e33751. doi: 10.1371/journal.pone. 0033751

Fretwell, P. T., and Trathan, P. N. (2009). Penguins from space?: faecal stains reveal the location of emperor penguin colonies. Glob. Ecol. Biogeogr. 18, 543-552. doi: 10.1111/j.1466-8238.2009.00467.x

Fretwell, P. T., and Trathan, P. N. (2019). Emperors on thin ice: three years of breeding failure at Halley Bay. Antarct. Sci. 31, 133-138. doi: 10.1017/ S0954102019000099 
Furness, R. W., and Camphuysen, K. C. J. (1997). Seabirds as monitors of the marine environment. ICES J. Mar. Sci. 54, 726-737. doi: 10.1006/jmsc.1997. 0243

Gagne, T. O., David Hyrenbach, K., Hagemann, M. E., and Van Houtan, K. S. (2018). Trophic signatures of seabirds suggest shifts in oceanic ecosystems. Sci. Adv. 4, 1-9. doi: 10.1126/sciadv.aao3946

Gownaris, N. J., Santora, C. M., Davis, J. B., and Pikitch, E. K. (2019). Gaps in protection of important ocean areas: a spatial meta-analysis of ten global mapping initiatives. Front. Mar. Sci. 6:650. doi: 10.3389/fmars.2019.00650

Grecian, W. J., Witt, M. J., Attrill, M. J., Bearhop, S., Godley, B. J., Grémillet, D., et al. (2012). A novel projection technique to identify important at-sea areas for seabird conservation: an example using Northern gannets breeding in the North East Atlantic. Biol. Conserv. 156, 43-52. doi: 10.1016/j.biocon.2011.12.010

Griffith, G., Hatterman, T., Høgestøl, A., Kasajima, Y., Lowther, A., Moreau, S., et al. (2019). SC-CAMLR-38/BG/14. Progress Report on the Scientific Data Compilation and Analyses in Support of the Planning of a Potential Marine Protected Area (MPA) East of the Zero Meridian in the Weddell Sea (Antarctica). Commission for the Conservation of Antarcti. Hobart: CCAMLR.

Grimm, V., Ayllón, D., and Railsback, S. F. (2016). Next-generation individualbased models integrate biodiversity and ecosystems: Yes we can, and yes we must. Ecosystems 20, 229-236. doi: 10.1007/s10021-016-0071-2

GSGSSI (2013). South Georgia and the South Sandwich Islands Marine Protected Area Management Plan. Version 2.0. Available online at: https://www.gov.gs/ docsarchive/environment/\#tab-2 (accessed August 31, 2013).

Halpern, B. S., Frazier, M., Potapenko, J., Casey, K. S., Koenig, K., Longo, C., et al. (2015). Spatial and temporal changes in cumulative human impacts on the world's ocean. Nat. Commun. 6, 1-7. doi: 10.1038/ncomms8615

Handley, J. M., Pearmain, E. J., Oppel, S., Carneiro, A. P. B., Hazin, C., Phillips, R. A., et al. (2020). Evaluating the effectiveness of a large multi-use MPA in protecting Key Biodiversity Areas for marine predators. Divers. Distrib. 26, 715-729. doi: 10.1111/ddi.13041

Hays, G. C., Bailey, H., Bograd, S. J., Bowen, W. D., Campagna, C., Carmichael, R. H., et al. (2019). Translating marine animal tracking data into conservation policy and management. Trends Ecol. Evol. 34, 459-473. doi: 10.1016/j.tree. 2019.01.009

Hazen, E. L., Abrahms, B., Brodie, S., Carroll, G., Jacox, M. G., Savoca, M. S., et al. (2019). Marine top predators as climate and ecosystem sentinels. Front. Ecol. Environ. 17:565-574. doi: 10.1002/fee.2125

Heerah, K., Dias, M. P., Delord, K., Oppel, S., Barbraud, C., Weimerskirch, H., et al. (2019). Important areas and conservation sites for a community of globally threatened marine predators of the Southern Indian Ocean. Biol. Conserv. 234, 192-201. doi: 10.1016/j.biocon.2019.03.037

Herman, R. W., Valls, F. C. L., Hart, T., Petry, M. V., Trivelpiece, W. Z., and Polito, M. J. (2017). Seasonal consistency and individual variation in foraging strategies differ among and within Pygoscelis penguin species in the Antarctic Peninsula region. Mar. Biol. 164:115. doi: 10.1007/s00227-017-3142-9

Hindell, M. A., Reisinger, R. R., Ropert-Coudert, Y., Hückstädt, L. A., Trathan, P. N., Bornemann, H., et al. (2020). Tracking of marine predators to protect Southern Ocean ecosystems. Nature 580, 87-92. doi: 10.1038/s41586-0202126-y

Hinke, J. T., Barbosa, A., Emmerson, L. M., Hart, T., Juáres, M. A., KorczakAbshire, M., et al. (2018). Estimating nest-level phenology and reproductive success of colonial seabirds using time-lapse cameras. Methods Ecol. Evol. 9, 1853-1863. doi: 10.1111/2041-210X.13015

Hinke, J. T., Cossio, A. M., Goebel, M. E., Reiss, C. S., Trivelpiece, W. Z., and Watters, G. M. (2017). Identifying risk: concurrent overlap of the antarctic krill fishery with krill-dependent predators in the scotia sea. PLoS One 12:e0170132. doi: 10.1371/journal.pone.0170132

Hinke, J. T., Santos, M., Korczak-Abshire, M., Milinevsky, G., and Watters, G. M. (2019). Individual variation in migratory movements of chinstrap penguins leads to widespread occupancy of ice-free winter habitats over the continental shelf and deep ocean basins of the Southern Ocean. PLoS One 14:e0226207. doi: 10.1371 /journal.pone.0226207

Hinke, J. T., and Trivelpiece, W. Z. (2011). Daily activity and minimum food requirements during winter for gentoo penguins (Pygoscelis papua) in the South Shetland. Polar Biol. 34, 1579-1590. doi: 10.1007/s00300-011-1018-x
Hothorn, T., Hornik, K., vande Wiel, M., and Zeileis, A. (2008). Implementing a class of permutation tests: The coin package. J. Stat. Softw. 28, 1-23. doi: 10.18637/jss.v028.i08

Hull, V., Rivera, C. J., and Wong, C. (2019). A synthesis of opportunities for applying the telecoupling framework to marine protected areas. Sustainability 11, 1-18. doi: 10.3390/su11164450

Humphreys, J., and Clark, R. W. E. (2020). Marine Protected Areas: Science, Policy and Management. Amsterdam: Elsevier.

Humphries, G. R. W., Naveen, R., Schwaller, M., Che-Castaldo, C., McDowall, P., Schrimpf, M., et al. (2017). Mapping application for penguin populations and projected dynamics (MAPPPD): Data and tools for dynamic management and decision support. Polar Rec. 53, 160-166. doi: 10.1017/S00322474170 00055

Iles, D. T., Lynch, H., Ji, R., Barbraud, C., Delord, K., and Jenouvrier, S. (2020). Sea ice predicts long-term trends in Adélie penguin population growth, but not annual fluctuations: results from a range-wide multiscale analysis. Glob. Chang. Biol. 26, 3788-3798. doi: 10.1111/gcb. 15085

IPBES (2019). Global Assessment Report on Biodiversity and Ecosystem Services of the Intergovernmental Science- Policy Platform on Biodiversity and Ecosystem Services. Bonn: IPBES Secretariat.

IPCC (2019). IPCC Special Report on the Ocean and Cryosphere in a Changing Climate, eds H. O. Pörtner, D. C. Roberts, V. Masson-Delmotte, P. Zhai, M. Tignor, E. Poloczanska, et al. (Geneva: IPCC).

IUCN (2016). A Global Standard for the Identification of Key Biodiversity Areas, Version 1.0. Gland: IUCN.

IUCN-MMPATF (2020). Global Dataset of Important Marine Mammal Areas(IUCN-IMMA).November 2020.Made Available Under Agreement on Terms of Use by the IUCN JOINT SSC/WCPA Marine Mammal Protected Areas Task Force and Made. Available online at: www.marinemammalhabitat.org/imma-eatlas

Javed, S., Elalqamy, H., Khan, S. B., Ahmed, S., Salem, S., Dhaheri, A., et al. (2019). Using greater flamingo tracking and count data in delineating marine protected areas in the coastal zone of Abu Dhabi, United Arab Emirates: Conservation planning in an economically important area. Glob. Ecol. Conserv. J. 17:e00557. doi: 10.1016/j.gecco.2019.e00557

Jenouvrier, S., Garnier, J., Patout, F., and Desvillettes, L. (2017). Influence of dispersal processes on the global dynamics of Emperor penguin, a species threatened by climate change. Biol. Conserv. 212, 63-73. doi: 10.1016/j.biocon. 2017.05.017

Jenouvrier, S., Holland, M., Iles, D., Labrousse, S., Landrum, L., Garnier, J., et al. (2019). The Paris Agreement objectives will likely halt future declines of emperor penguins. Glob. Chang. Biol. 26, 1170-1184. doi: 10.1111/gcb.14864

Jenouvrier, S., Holland, M., Stroeve, J., Serreze, M., Barbraud, C., Weimerskirch, H., et al. (2014). Projected continent-wide declines of the emperor penguin under climate change. Nat. Clim. Chang. 4, 715-718. doi: 10.1038/NCLIMATE2280

Johnson, D., Barrio Froján, C., Bax, N., Dunstan, P., Woolley, S., Halpin, P., et al. (2019). The global ocean biodiversity initiative: promoting scientific support for global ocean governance. Aquat. Conserv. Mar. Freshw. Ecosyst. 29, 162-169. doi: 10.1002/aqc.3024

Jones, F. M., Allen, C., Arteta, C., Arthur, J., Black, C., Emmerson, L. M., et al. (2018). Data Descriptor?: time-lapse imagery and volunteer classifications from the zooniverse Penguin watch project. Sci. Data 5:180124.

Jovani, R., Lascelles, B., Garamszegi, L. Z., Mavor, R., Thaxter, C. B., and Oro, D. (2016). Colony size and foraging range in seabirds. Oikos 125, 968-974. doi: 10.1111/oik.02781

Klein, E. S., and Watters, G. M. (2020a). Comparing feedback and spatial approaches to advance ecosystem-based fisheries management in a changing Antarctic. PLoS One 15:e0231954. doi: 10.1371/journal.pone.0231954

Klein, E. S., and Watters, G. M. (2020b). What's the catch? Profiling the benefits and costs associated with marine protected areas and displaced fishing in the Scotia Sea. PLoS One 15:e0237425. doi: 10.1371/journal.pone.0237425

Krüger, L., Huerta, M. F., Santa Cruz, F., and Cárdenas, C. A. (2020). Antarctic krill fishery effects over penguin populations under adverse climate conditions: Implications for the management of fishing practices. Ambio doi: 10.1007/ s13280-020-01386-w 
Lascelles, B. G., Taylor, P. R., Miller, M. G. R., Dias, M. P., Oppel, S., Torres, L., et al. (2016). Applying global criteria to tracking data to define important areas for marine conservation. Divers. Distrib. 22, 422-431. doi: 10.1111/ddi.12411

Lescroël, A., and Bost, C.-A. (2005). Foraging under contrasting oceanographic conditions: the gentoo penguin at Kerguelen archipelago. Mar. Ecol. Prog. Ser. 302, 245-261. doi: 10.3354/meps302245

Ludynia, K., Kemper, J., and Roux, J. (2012). The Namibian Islands' marine protected area: using seabird tracking data to define boundaries and assess their adequacy. Biol. Conserv. 156, 136-145. doi: 10.1016/j.biocon.2011. 11.014

Lynch, H. J. (2013). "The Gentoo penguin (Pygoscelis papua)," in Biology and Conservation of the World's Penguins, eds P. G. Borborough and P. D. Boersma (Seattle: University of Washington Press).

Lynch, H. J., and LaRue, M. A. (2014). First global census of the Adélie Penguin. Auk 131, 457-466. doi: 10.1642/auk-14-31.1

Lynch, H. J., White, R. W., Black, A., and Naveen, R. (2012). Detection, differentiation, and abundance estimation of penguin species by highresolution satellite imagery. Polar Biol. 35, 963-968. doi: 10.1007/s00300-0111138-3

Lyver, P. O. B., Barron, M., Barton, K. J., Ainley, D. G., Pollard, A., Gordon, S., et al. (2014). Trends in the breeding population of Adélie penguins in the Ross Sea, 1981-2012: A coincidence of climate and resource extraction effects. PLoS One 9:e9118. doi: 10.1371/journal.pone.0091188

Maxwell, S. L., Fuller, R. A., Brooks, T. M., and Watson, J. E. M. (2016). Biodiversity: The ravages of guns, nets and bulldozers. Nature 536, 143-145. doi: $10.1038 / 536143 a$

Miller, A. K., Karnovsky, N. J., and Trivelpiece, W. Z. (2009). Flexible foraging strategies of gentoo penguins Pygoscelis papua over 5 years in the South Shetland Islands, Antarctica. Mar. Biol. 156, 2527-2537. doi: 10.1007/s00227009-1277-z

Nicol, S., and Foster, J. (2016). "The fishery for antarctic krill: its current status and management regime," in Biology and Ecology of Antarctic krill, ed. V. Siegel (Berlin: Springer International), 387-422. doi: 10.1007/978-3-319-29279-3_11

Oppel, S., Bolton, M., Carneiro, A. P. B., Dias, M. P., Green, J. A., Masello, J. F., et al. (2018). Spatial scales of marine conservation management for breeding seabirds. Mar. Policy 98, 37-46. doi: 10.1016/j.marpol.2018.08.024

Ratcliffe, N., and Trathan, P. (2011). A review of the diet and at-sea distribution of penguins breeding within the CAMLR convention area. CCAMLR Sci. 18, 75-114.

Rey, A. R., and Huettmann, F. (2020). Telecoupling analysis of the Patagonian Shelf: A new approach to study global seabird-fisheries interactions to achieve sustainability. J. Nat. Conserv. 53, 125748. doi: 10.1016/j.jnc.2019.125748

Rintoul, S. R., Chown, S. L., Deconto, R. M., England, M. H., Fricker, H. A., Masson-Delmotte, V., et al. (2018). Choosing the future of Antarctica. Nature 558, 233-241. doi: 10.1038/s41586-018-0173-4

Rogers, A. D., Frinault, B. A. V., Barnes, D. K. A., Bindoff, N. L., Downie, R., Ducklow, H. W., et al. (2020). Antarctic Futures: An Assessment of ClimateDriven Changes in Ecosystem Structure, Function, and Service Provisioning in the Southern Ocean. Ann. Rev. Mar. Sci. 12, 87-120. doi: 10.1146/annurevmarine-010419-011028

Ropert-Coudert, Y., Chiaradia, A., Ainley, D., Barbosa, A., Boersma, P. D., Brasso, R., et al. (2019). Happy feet in a hostile world? The future of penguins depends on proactive management of current and expected threats. Front. Mar. Sci. 6:248. doi: 10.3389/fmars.2019.00248

Ropert-Coudert, Y., Wilson, R. P., Daunt, F., and Kato, A. (2004). Patterns of energy acquisition by a central place forager: Benefits of alternating short and long foraging trips. Behav. Ecol. 15, 824-830. doi: 10.1093/beheco/arh086

SANPARKS (2020). The Robben Island Marine Protected Area Managed by Table Mountain National Park. Available online at: https://www.sanparks.org/mpa/ robben-island-marine-protected-area.php (accessed November 15, 2020).

Santora, J. A., LaRue, M. A., and Ainley, D. G. (2020). Geographic structuring of Antarctic penguin populations. Glob. Ecol. Biogeogr. 29, 1716-1728. doi: 10.1111/geb.13144

Sherley, R. B., Winker, H., Altwegg, R., Van Der Lingen, C. D., Votier, S. C., and Crawford, R. J. M. (2015). Bottom-up effects of a no-take zone on endangered penguin demographics. Biol. Lett. 11, 4-7. doi: 10.1098/rsbl.2015.0237

Smith, R. J., Bennun, L., Brooks, T. M., Butchart, S. H. M., Cuttelod, A., Di Marco, M., et al. (2019). Synergies between the key biodiversity area and systematic conservation planning approaches. Conserv. Lett. 12:e12625. doi: 10.1111/conl. 12625

Soanes, L. M., Bright, J. A., Angel, L. P., Arnould, J. P. Y., Bolton, M., Berlincourt, M., et al. (2016). Defining marine important bird areas: Testing the foraging radius approach. Biol. Conserv. 196, 69-79. doi: 10.1016/j.biocon.2016.02.007

Southwell, C., and Emmerson, L. (2015). Remotely-operating camera network expands Antarctic seabird observations of key breeding parameters for ecosystem monitoring and management. J. Nat. Conserv. 23, 1-8. doi: 10.1016/ j.jnc.2014.11.002

Southwell, C., McKinlay, J., Low, M., Wilson, D., Newbery, K., Lieser, J. L., et al. (2013). New methods and technologies for regional-scale abundance estimation of land-breeding marine animals: Application to Adélie penguin populations in East Antarctica. Polar Biol. 36, 843-856. doi: 10.1007/s00300-013-1310-z

Strimas-Mackey, M. (2018). Smoothr: Smooth and Tidy Spatial Features. $R$ Package Version 0.1.0. Available online at: https://CRAN.R-project.org/ package $=$ smoothr

Strycker, N., Wethington, M., Borowicz, A., Forrest, S., Witharana, C., Hart, T., et al. (2020). A global population assessment of the Chinstrap penguin (Pygoscelis antarctica). Sci. Rep. 10, 1-11. doi: 10.1038/s41598-020-76479-3

Sylvester, Z. T., and Brooks, C. M. (2020). Protecting Antarctica through Coproduction of actionable science: Lessons from the CCAMLR marine protected area process. Mar. Policy 111:103720. doi: 10.1016/j.marpol.2019.103720

Takahashi, A., Watanuki, Y., Sato, K., Kato, A., Arai, N., Nishikawa, J., et al. (2003). Parental foraging effort and offspring growth in Adélie Penguins: does working hard improve reproductive success? Funct. Ecol. 17, 590-597. doi: 10.1046/j.1365-2435.2003.00772.x

Teschke, K., Pehlke, H., Siegel, V., Bornemann, H., Knust, R., and Brey, T. (2020). An integrated data compilation for the development of a marine protected area in the Weddell Sea. Earth Syst. Sci. Data Discuss. 899:667. doi: 10.5194/essd2019-86

Thaxter, C. B., Lascelles, B., Sugar, K., Cook, A. S. C. P., Roos, S., Bolton, M., et al. (2012). Seabird foraging ranges as a preliminary tool for identifying candidate Marine Protected Areas. Biol. Conserv. 156, 53-61. doi: 10.1016/j.biocon.2011. 12.009

Thiebot, J., Ropert-coudert, Y., Raclot, T., and Poupart, T. (2019). Adélie penguins' extensive seasonal migration supports dynamic Marine Protected Area planning in Antarctica. Mar. Policy 109:103692. doi: 10.1016/j.marpol. 2019.103692

Trathan, P. N., García-Borboroglu, P., Boersma, D., Bost, C. A., Crawford, R. J. M., Crossin, G. T., et al. (2014). Pollution, habitat loss, fishing, and climate change as critical threats to penguins. Conserv. Biol. 29, 31-41. doi: 10.1111/cobi.12349

Trathan, P. N., and Grant, S. M. (2019). “The South Orkney Islands Southern shelf marine protected area: towards the establishment of marine spatial protection within international waters in the Southern Ocean," in Marine Protected Areas: Science, Policy and Management, eds J. Humphreys and R. W. E. Clark (Oxford: Elsevier).

Trathan, P. N., Warwick-Evans, V., Hinke, J. T., Young, E. F., Murphy, E. J., Carneiro, A. P. B., et al. (2018). Managing fishery development in sensitive ecosystems: identifying penguin habitat use to direct management in Antarctica. Ecosphere 9:e02392. doi: 10.1002/ecs2.2392

Trathan, P. N., Wienecke, B., Barbraud, C., Jenouvrier, S., Kooyman, G., Le, C., et al. (2019). The emperor penguin - Vulnerable to projected rates of warming and sea ice loss. Biol. Conserv. 241:108216. doi: 10.1016/j.biocon.2019. 108216

Trivelpiece, W. Z., Buckelew, S., Reiss, C., and Trivelpiece, S. G. (2007). The winter distribution of chinstrap penguins from two breeding sites in the South Shetland Islands of Antarctica. Polar Biol. 30, 1231-1237. doi: 10.1007/s00300007-0283-1

UN General Assembly (2015). Transforming Our World?: the 2030 Agenda for Sustainable Development, 21 October 2015, A/RES/70/1. Available online at: https://www.refworld.org/docid/57b6e3e44.html (accessed March 15, 2019).

Velarde, E., ANderson, D. W., and Ezcurra, E. (2019). Seabird monitoring provides essential information on the state of marine ecosystems. Science 365, 116-117.

Visconti, B. P., Butchart, S. H. M., Brooks, T. M., Langhammer, P. F., Marnewick, D., Vergara, S., et al. (2019). Protected area targets post-2020. Science 364, 239-241. doi: 10.1126/science.aav6886

Wakefield, E. D., Owen, E., Baer, J., Carroll, M. J., Daunt, F., Dodd, S. G., et al. (2017). Breeding density, fine-scale tracking, and large-scale modeling reveal 
the regional distribution of four seabird species. Ecol. Appl. 27, 2074-2091. doi: 10.1002/eap.1591

Waliczky, Z., Fishpool, L., Butchart, S. H. M., Thomas, D., Heath, M., Donald, P., et al. (2018). Important Bird and Biodiversity Areas (IBAs): their impact on conservation policy, advocacy and action. Bird Conserv. Int. 29, 1-17. doi: $10.1017 /$ S0959270918000175

Warwick-Evans, V., Atkinson, P. W., Walkington, I., and Green, J. A. (2017). Predicting the impacts of wind farms on seabirds: An individual-based model. J. Appl. Ecol. 55, 503-515. doi: 10.1111/1365-2664.12996

Warwick-Evans, V., Downie, R., Santos, M., and Trathan, P. N. (2019). Habitat preferences of Adélie Pygoscelis adeliae and Chinstrap Penguins Pygoscelis antarctica during pre-moult in the Weddell Sea (Southern Ocean). Polar Biol. 42, 703-714. doi: 10.1007/s00300-019-02465-9

Warwick-Evans, V., Ratcliffe, N., Lowther, A. D., Manco, F., Ireland, L., Clewlow, H. L., et al. (2018). Using habitat models for chinstrap penguins Pygoscelis antarctica to advise krill fisheries management during the penguin breeding season. Divers. Distrib. 24, 1756-1771. doi: 10.1111/ddi.12817

Watson, J. E. M., Dudley, N., Segan, D. B., and Hockings, M. (2014). The performance and potential of protected areas. Nature 515, 67-73. doi: 10.1038/ nature13947

Watters, G. M., Hinke, J. T., and Reiss, C. S. (2020). Long-term observations from Antarctica demonstrate that mismatched scales of fisheries management and predator-prey interaction lead to erroneous conclusions about precaution. Sci. Rep. 10, 1-9. doi: 10.1038/s41598-020-59223-9

Wienecke, B. (2012). Emperor penguins at the West Ice Shelf. Polar Biol 35, 1289-1296. doi: 10.1007/s00300-012-1172-9

Wilson, R. P., Alvarrez, B., Latorre, L., Adelung, D., Culik, B., and Bannasch, R. (1998). The movements of gentoo penguins Pygoscelis papua from Ardley Island, Antarctica. Polar Biol. 19, 407-413. doi: 10.1007/s003000050266
Youngflesh, C., Jenouvrier, S., Li, Y., Ji, R., Ainley, D. G., Ballard, G., et al. (2017). Circumpolar analysis of the Adélie Penguin reveals the importance of environmental variability in phenological mismatch. Ecology 98, 940-951. doi: $10.1111 /$ ijlh. 12426

Zhang, J., Dennis, T. E., Landers, T. J., Bell, E., and Perry, G. L. W. (2017). Linking individual-based and statistical inferential models in movement ecology: a case study with black petrels (Procellaria parkinsoni). Ecol. Modell. 360, 425-436. doi: 10.1016/j.ecolmodel.2017. 07.017

Zhao, Q., Stephenson, F., Lundquist, C., Kaschner, K., Jayathilake, D., and Costello, M. J. (2020). Where marine protected areas would best represent $30 \%$ of ocean biodiversity. Biol. Conserv. 244:108536. doi: 10.1016/j.biocon.2020. 108536

Conflict of Interest: The authors declare that the research was conducted in the absence of any commercial or financial relationships that could be construed as a potential conflict of interest.

The reviewer AW declared a past co-authorship with one of the authors PT to the handling editor.

Copyright ( 2021 Handley, Rouyer, Pearmain, Warwick-Evans, Teschke, Hinke, Lynch, Emmerson, Southwell, Griffith, Cárdenas, Franco, Trathan and Dias. This is an open-access article distributed under the terms of the Creative Commons Attribution License (CC BY). The use, distribution or reproduction in other forums is permitted, provided the original author(s) and the copyright owner(s) are credited and that the original publication in this journal is cited, in accordance with accepted academic practice. No use, distribution or reproduction is permitted which does not comply with these terms. 